\title{
KAJIAN STRUKTURAL DAN NILAI-NILAI PENDIDIKAN DALAM NOVEL HAYYA KARYA HELVY TIANA ROSA DAN BENNY ARNAS
}

\author{
Husnul Septiana ${ }^{1}$, Siti Isnaniah ${ }^{2}$ \\ ${ }^{1,2}$ Program Studi Tadris Bahasa Indonesia \\ Institut Agama Islam Negeri Surakarta \\ Author correspondence: husnulseptiana8@gmail.com,
}

\begin{abstract}
Abstrak
Permasalahan penelitian ini adalah (1) Bagaimanakah kajian struktural dalam novel Hayya karya Helvy Tiana Rosa dan Benny Arnas? (2) Bagaimanakah nilai-nilai pendidikan dalam novel Hayya karya Helvy Tiana Rosa dan Benny Arnas? Tujuan penelitian ini adalah (1) Mendeskripsikan Bagaimanakah kajian struktural dalam novel Hayya karya Helvy Tiana Rosa dan Benny Arnas (2) Mendeskripsikan nilai-nilai pendidikan dalam novel Hayya karya Helvy Tiana Rosa dan Benny Arnas. Teknik yang digunakan dalam penelitian ini terdiri dari teknik pengumpulan data menggunakan studi kepustakaan. Pada metode analilis data digunakan deskripsi kualitatif. Sumber data yang digunakan adalah dokumen, naskah novel Hayya. Teknik pengumpulan data yang digunakan adalah teknik analilis isi dokumen (baca-cacat-analisis). Teknik analilis data yang digunakan adalah analilis strukturalisme berupa unsur intrinsik. Hasil yang diperoleh dari penelitian ini berupa (1) Struktural yang terkandung dalam novel Hayya karya Helvy Tiana Rosa dan Benny Arnas, yaitu: Tema, tokoh Latar. Alur, Sudut pandang (2) Nilai-nilai pendidikan dalam novel Hayya karya Helvy Tiana Rosa dan Benny Arnas meliputi: Nilai pendidikan religius: membaca quran, mengucapkan kalimat toyyibah (kalimat yang baik), dzikir, berjuang di jalan Allah (jihad), dan menghindari zina perasaan. Nilai pendidikan sosial: memuliakan tamu serta adab bertamu. Nilai pendidikan budaya: adat pernikahan daerah Ciamis tentu berbeda dengan di Jakarta yang cenderung menggunakan Wedding Organizer. Nilai pendidikan karakter: menghormati orang yang lebih tua.
\end{abstract}

Kata Kunci: Novel, Struktural, Nilai-nilai Pendidikan

\section{PENDAHULUAN}

Pembahasan tentang sastra oleh para ahli sastra mengungkapkan bahwa definisi sastra diungkapkan berbeda-beda. Jika dilihat secara etimologis sastra ialah karangan. Sastra tidak mampu didefinisikan secara lahiriah sebab keindahan mencakup aspek yang luas, sehingga tidak ada definisi mutlak pendapatnya salah seorang sastrawan mana yang paling benar. Sejatinya dari definisi yang mereka kemukakan memiliki persamaan yaitu bahwa sastra ialah suatu karya, ciptaan, kreasi yang tidak mengacu kepada sesuatu lain, salah satu cirinya ialah koherensi dengan mengungkapkan sesuatu yang tak terungkapkan dan mengandung nilai estetika, nilai moral dan nilai yang bersifat konsepsional.

Karya sastra yang dikenal oleh masyarakat seperti novel, dongeng, legenda, puisi, sajak, dan drama. Hadirnya karya sastra dimaksudkan untuk memberikan nilai pendidikan kepada masyarakat. Mengingat hubungan antara sastra dengan masyarakat yang sangat erat kaitannya. Seperti nilai budaya, nilai pendidikan, nilai agama, nilai sosial, dan nilai masyarakat.

Pengarang melakukan penelitian karena erat kaitannya dengan kehidupan masyarakat. Hal ini sesuai dengan asumsi kesusasteraan yang merupakan ungkapan fakta imajinatif dan artistik sebagai manifestasi kehidupan di masyarakat melalui sebuah bahasa dan dapat memberikan dampak pada kehidupan bermasyarakat (Esten, 2013: 3).

Salah satu karya sastra, novel yang menarik dikaji berdasarkan struktur dan nilai-nilai pendidikan adalah novel Hayya karya Helvy Tiana Rosa dan Benny Arnas yang terbit pada tahun 2019. Diterbitkan oleh Aman Palestin dan novel ini belum banyak terjamah seperti karya Helvy Tiana Rosa yang sebelumnya 
seperti Ketika Mas Gagah Pergi (KMGP) dan Duka Sedalam Cinta (DSC) dan 212 The Power of Love hingga di tampilkan di layar lebar.

Ciri karya sastra Helvy Tiana Rosa selalu memberikan pengertian tentang agama Islam yang dikemas dengan santai tanpa menggurui. Mengingat para remaja dewasa ini maka jenuh jika harus belajar agama melalui buku yang formal. Mereka akan lebih tertarik jika disajikan kedalam bentuk novel. Tokoh-tokoh dalam novel Hayya mempresentasikan strukturalisme dan nilai-nilai pendidikan yang pantas ditiru oleh masyarakat dari segala usia. Kehadiran novel Hayya yang disampaikan dengan bahasa yang santun, sederhana (mudah dipahami), dengan beberapa kosa-kata bahasa anak milenial (bahasa yang sedang trend, bahasa yang sering digunakan anak-anak remaja saat ini) ternyata mampu menyampaikan nilai-nilai pendidikan kepada masyarakat tanpa bermaksud menggurui dan terkesan paling tahu dan benar.

Kedatangan novel Hayya yang kemudian di filmkan adalah fenomena yang cukup banyak menyita perhatian masyarakat luas dari segala kalangan dan usia, bahkan media massa, baik cetak maupun elektronik, mengingat film Hayya masuk nominasi sebagai film yang banyak dilihat orang di bioskop. Tayang perdana pada tanggal 19 September 2019 yang merangkul nyaris 100 ribu penonton kemudian disebar dalam bentuk infografik sejumlah 93.276 penonton. Film Hayya yang diperkuat oleh sejumlah bintang diantaranya Fauzi Baadila, Ria Ricis, Meyda Safira dan lain-lain.

Sebelum kehadiran novel Hayya, Helvy Tiana Rosa bersama Benny Arnas sudah lebih dulu membuat novel 212 The Power Of Love dan juga di filmkan. Novel Hayya merupakan kelanjutan cerita dari novel 212 The Power Of Love, keduanya sukses menyita perhatian masyarakat. Cerita yang disuguhkan banyak mengajarkan nilai-nilai Islam, toleransi, nilai-nilai pendidikan serta khazanah keilmuan tentang sejarah. Novel Hayya tersebut dinilai banyak memberikan pencerahan baru terutama terhadap kondisi anak-anak Palestina. Setelah membaca novel Hayya banyak masyarakat yang mengalami perubahan baik karena tersentuh oleh nilai-nilai yang ada di dalamnya.

Helvy Tiana Rosa adalah salah satu perempuan di Universitas Negeri Jakarta (UNJ) masuk Fakultas Bahasa dan Seni, sebagai akademikus. Selain seorang novelis, dari karya sastra pertamanya yang diterbitkan sebagai buku tahun 1997 (Ketika Mas Gagah Pergi/ KMGP). Helvy Tiana Rosa atau bunda Helvy ini masuk dalam daftar 500 muslim paling berpengaruh di dunia. Diumumkan dalam acara The Royal Islamic Strategic Studies Centre Jordan. Adapun Benny Arnas merupakan alumnus Fakultas Pertanian Universitas Andalas . Ia menjadi sastrawan terpilih dalam sebuah program yang diadakan oleh badan bahasa sastrawan berkarya di wilayah 3T, berawal dari judul Seram Bagian Barat (2018) dan berhasil menciptakan buku Catatan Perjalanan Berburu Suami (Badan Bahasa, 2018). Selain itu, jabatan sebagai ketua umum pada Forum Lingkar Pena (FLP) di Lubuklinggau pernah ia jabat.

Novel Hayya berlatar Palestina dan Indonesia. Ketika novel Hayya di filmkan menjadi film pertama yang melakukan syuting di Palestina. Pola percintaan yang dibingkai dalam koridor muhrim- bukan muhrim merupakan bagian penting yang menjadikan beda dengan novel lain yang terbit sebelumnya. Dalam novel Hayya juga disinggung masalah ta'aruf (perkenalan menuju jenjang pernikahan) dan khitbah (lamaran). Selain itu muncul humor yang membuat novel tidak terkesan kaku. Kekhasan itu didukung oleh narasinya yang mengalir santai, kekayaan uangkapan-ungkapan Arab, Malaysia dan gaya bahasa yang hiperbolis.

Oleh sebab itu, penelitian tentang novel Hayya pantas dilakukan karena novel tersebut memuat nilainilai pendidikan terutama dapat memberikan kontribusi untuk para remaja (siswa), guru sebagai bahan ajar dan bentuk apresiasi terhadap karya sastra dan kepada masyarakat dalam kehidupan sehari-hari.

Pendidikan nilai akan mudah diterima oleh siswa jika guru bisa mengajarkannya dengan media dan metode yang tepat (Ingvarson dalam Isnaniah, 2014: 6) karena sejauh ini pembelajaran sastra masih dianggap berat sebelah oleh berbagai pihak. Pembelajaran sastra akan berhasil jika didukung oleh berbagai pihak terutama guru dan siswa. 
Isnaniah (2014: 6) mengungkapkan sejumlah fakta di lapangan yang menyatakan bahwa pembelajaran sastra di Indonesia masih rendah. Hal tersebut dipengaruhi oleh beberapa hal sebagai berikut (1) minimnya buku-buku karya sastra di sekolah sehingga siswa dan guru tidak maksimal dalam mengapresiasi. (2) masih rendahnya minat baca murid dan guru terhadap sastra sehingga persaingan dan pengetahuan mereka tentang sastra juga kurang. Sejak awal berdirinya kurikulum di Indonesia hingga kurikulum 2013, guru selalu dituntut kompeten dalam bahasa dan sastra sebab sastra memang selalu disatukan dengan mata pelajaran bahasa Indonesia sehingga kompettensi guru dalam bahasa dan sastra kadang kurang maksimal. (3) dalam pembelajaran sastra siswa kurang berminat karena ditempatkan sebagai katagori pelajaran yang kurang diperkirakan. Dan (4) kondisi dan situasi sekolah kurang mendukung. Hal tersebut sepadan dengan pendapat Andayani (dalam Isnaniah, 2014: 7) bahwa pembelajaran bahasa dan sastra Indonesia tidak digunakan secara konsisten bahkan dalam situasi formal meskipun bahasa Indonesia menjadi syarat kelulusan dalam semua jenjang pendidikan. Sebagai syarat kelulusan, bahasa Indonesia hanya menjadi bahan belajar tentang teori-teori yang kurang aplikatif sehingga hal tersebut mendatangkan berbagai tuduhan terhadap kekurangberhasilan pembelajaran bahasa Indonesia saat ini. Berdasarkan semua pernyataan yang sudah di paparkan diatas maka penelitian tentang novel Hayya secara struktural dan nilainilai pendidikan pantas untuk dilakukan. Sebelumnya beberapa peneliti berhasil melakukan penelitian yang berkaitan dengan penelitian peneliti. Didalam kajian pustaka inilah hasil penelitian yang relevan. Persamaan, perbedaan dan pembaharuan apa saja yang dimunculkan pengarang. Beberapa penelitian yang menjadi acuan penelitian peneliti: Pertama, penelitian Akbar, Winarni, Retno dan Andayani (2013) tentang "Kajian Sosiologi Sastra dan Nilai Pendidikan Dalam Novel Tuan Guru Karya Salman Faris". Mengkaji tentang sosial budaya masyarakat Lombok dan kehidupan religius. Peneliti menggunakan kajian sosiologi sastra. Hasil penelitian menjelaskan mayoritas masyarakat Lombok Timur menganggap Tuan Guru menjamin garansi masuk Surga, berdoa lebih mudah terkabul dan didengar oleh Allah dibandingkan masyarakat dan manusia yang lain. Tuan Guru dianggap sempurna tanpa celah dan dosa, latar belakang sosial budaya mencakup pekerjaan, pendidikan, adat istiadat dan kepercayaan, tempat tinggal, bahasa, suku dan agama. Adapun nilai-nilai pendidikan di dalamnya adalah pendidikan budaya, pendidikan sosial, moral, politik, historis, ekonomi, dan agama. Terdapat persamaan dan perbedaan antara Penelitian Akbar, Winarni, Retno dan Andayani (2013) dengan peneliti. Persaman antara keduanya ialah membahas tentang analisis struktur novel, dan nilai pendidikannya. Perbedaannya terdapat pada objek kajian yang menggunakan kajian sosiologi sastra, sedangkan penelitian peneliti membahas kajian struktural.

Kedua, penelitian Sujarwanto, Al-Ma'ruf dan Sunanda (2018) tentang "Nilai Budaya Pada Novel Anak Rantau Karya Ahmad Fuadi: Kajian Antropologi Sastra dan Implementasinya dalam Pembelajaran Sastra di SMA". Penelitian ini mendeskrepsikan sosiohistoris latar belakang dari Ahmad Fuadi, anak kelahiran Minang. Hasil dari penelitian tersebut adalah (1) Latar sosiohistoris Ahmad Fuadi adalah orang kelahiran Minang dan sudah memiliki karya. Non fiksi dan fiksi. (2) novel ini bertema pendidikan agama tokoh utama Hepi, alur dalam cerita maju dan berlatar di dua tempat yaitu Kampung Tanjung Durian di Minang dan Jakarta. (3) nilai budaya dalam novel Anak Rantau dibagi menjadi lima, yaitu hubungan manusia dengan, hubungan manusia dengan orang lain, hubungan manusia dengan Tuhan, nilai budaya dalam hubungan manusia dengan dirinya sendiri dan hubungan manusia dengan alam. Hasil penelitian ini juga dapat diimplementasikan dalam pembelajaran sastra di SMA/ MA Kelas XI karena telah memenuhi kriteria bahan ajar yaitu dari segi psikologi, latar belakang kebudayaan siswa dan sudut bahasa. Terdapat persamaan dan perbedaan penelitian Sujarwanto, Al-Ma'ruf dan Sunanda (2018) dengan peneliti.

Persamaan diantara keduanya ialah membahas tentang struktur dalam karya sastra berupa novel. Perbedaannya terdapat pada objek kajian sebelumnya menggunakan sosiohistoris dengan ditambahkan implementasi nilai pendidikan di SMA, sedangkan penelitian peneliti menggunakan kajian struktural (unsur intrinsik) dan nilai-nilai pendidikan.

Ketiga, penelitian Syarifuddin (2018) tentang "Kajian Struktural Dan Sosiologi Sastra Dalam Novel Seputih Hati Yang Tercabik". Penelitian ini bertujuan untuk menganalisis dan mendeskripsikan struktur novel dan menjelaskan sosiologi yang dialami oleh tokoh utama dalam novel. Hasil dari penelitian ini 
adalah keadaan hidup tokoh utama dalam novel Seputih Hati yang Tercabik Karya Ratu Wardarita yang bernama Ida Kusuma. Tokoh utama adalah perempuan yang diceritakan memiliki sifat tegar dalam berumah tangga. Novel tersebut berkisah tentang perjuangan hidup tokoh utama beserta aspek budaya yang masih kuat di daerah tersebut. Terdapat persamaan dan perbedaan penelitian Syarifuddin (2018) tentang "Kajian Struktural Dan Sosiologi Sastra Dalam Novel Seputih Hati Yang Tercabik".

Persamaannya ialah penelitian sebelumnya dengan peneliti terletak pada objek kajiannya yaitu kajian struktural dalam novel. Perbedaannya yaitu peneliti sebelumnya dengan penelitian peneliti ialah penelitian sebelumnya memaparkan aspek sosiologi sastra sedangkan penelitian peneliti memaparkan nilai-nilai pendidikan dalam novel.

Keempat, penelitian Junaini, Agustina dan Canrhas (2017) tentang “Analilis Nilai Pendidikan Karakter Dalam Cerita Rakyat Seluma". Penelitian ini bertujuan untuk mendeskripsikan nilai pendidikan karakter yang terdapat dalam cerita rakyat Seluma. Hasil dari penelitian ini menunjukan nilai-nilai karakter dalam cerita rakyat Seluma karena nilai pendidikan didalamnya sangat dekat dengan kehidupan sehari-hari sehingga bermanfaat untuk sebuah motivasi. Adapun nilai yang terkandung didalamnya adalah sikap saling membutuhkan, sikap gotong royong, saling melindungi, sikap bermusyawarah, sikap hormat pada orang lain, sikap disiplin diri, sikap adail, penghormatan terhadap diri sendiri dan nilai keberanian. Terdapat persamaan dan perbedaan penelitian Junaini, Agustina dan Canrhas (2017) dengan penelitian peneliti.

Persamaan diantara keduannya adalah sama-sama membahas tentang nilai pendidikan. Perbedaannya terdapat pada objek kajiannya berupa cerita rakyat sedangkan objek penelitian peneliti berupa novel.

Kelima, penelitian Istiqomah (2014) tentang "Nilai-nilai Pendidikan Karakter Dalam Novel 9 Matahari Karya Adenita". Penelitian ini bertujuan untuk menggambarkan nilai-nilai pendidikan karakter. Hasil dari penelitian ini adalah (1) nilai-nilai karakter dalam novel 9 Matahari karya Adenita: keadilan, ketabahan, pengendalian diri, krendahan hati, berterimaksih, ketulusan hati, kerja keras, sikap positif, kasih, dan kebijaksanaan. (2) Strategi internalisasi nilai-nilai karakter terhadap kehidupan mahasiswa dan masyarakat: keteladanan, pengkondisian lingkungan, kegiatan rutin, pembiasaan nilai-nilai dan perilaku luhur, dan kegiatan spontan. Terdapat persamaan dan perbedaan penelitian Istiqomah (2014) dengan penelitian peneliti.

Persamaan diantara keduanya ialah membahas tentang nilai-nilai pendidikan dalam novel. Perbedaan diantara keduanya terdapat pada objek kajian. Penelitian sebelumnya hanya mengkaji nilai-nilai pendidikan dalam novel sedangkan penelitian peneliti mengkaji nilai-nilai pendidikan beserta kajian struktural.

\section{Kerangka Berpikir}

Adapun kerangka berpiki dalam penelitian ini dapat digambarkan sebagai berikut:

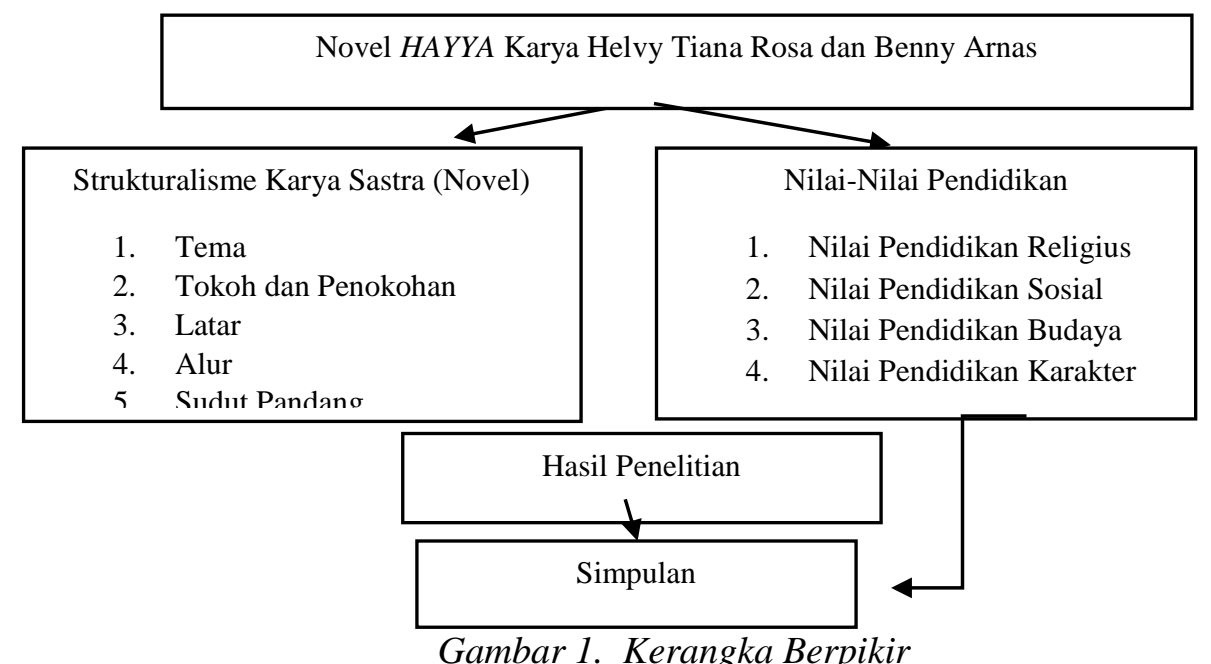




\section{Tujuan Penelitian}

Penelitian ini bertujuan untuk mendeskripsikan:

1. Kajian struktural dalam novel Hayya karya Helvy Tiana Rosa dan Benny Arnas

2. Nilai-nilai pendidikan dalam novel Hayya karya Helvy Tiana Rosa dan Benny Arnas

\section{METODE PENELITIAN}

\section{Jenis Penelitian}

Metode yang diterapkan pada penelitian ini bersifat deskriptif kualitatif, yakni proses penelitian yang ditunjukan untuk mendeskripsikan atau menggambarkan atau menjelaskan peristiwa yang terjadi, baik yang bersifat rekayasa manusia maupun alamiah. Adapun jenis penelitian deskriptif kualitatif dalam penelitian ini adalah analisis isi, yakni penelitian yang bertujuan untuk menghimpun dan menganalisis dokumendokumen resmi, dokumen yang valid, dan hasil penelitian.

\section{Sumber Data}

Sumber data dalam penelitian ini adalah dokumen yang didapatkan melalui novel Hayya karya Helvy Tiana Rosa dan Benny Arnas dengan tebal 264 halaman, diterbitkan oleh Aman Palestin.

\section{Teknik Pengumpulan Data}

Menurut Sukmadinata (dalam Isnaniah. 2014: 112-113) Teknik pengumpulan data yang dapat diterapkan sebagai alat untuk mencari data secara akurat dan lengkap berkaitan dengan permasalahan yang akan diteliti: teknik analisis isi dokumen (baca-catat-analisis), teknik ini digunakan untuk mendapatkan data tentang pengarang, aspek struktural dalam novel Hayya karya Helvy Tiana Rosa dan Benny Arnas, serta nilai-nilai pendidikan karakter dalam novel Hayya karya Helvy Tiana Rosa dan Benny Arnas. Dokumen yang dimaksud adalah novel Hayya karya Helvy Tiana Rosa dan Benny Arnas. Sistematika kerja teknik analilis isi dokumen adalah peneliti mengumpulkan data dari novel Hayya yang memuat unsur intrinsik dalam novel (kajian struktural), serta nilai-nilai pendidikan. Isi data tersebut kemudian diurai/ dianalilis, dibandingkan, dan disintesiskan membentuk hasil kajian yang padu, utuh dan sistematis.

Jadi teknik ini bukan hanya sekedar menuliskan, melaporkan, dan mengumpulkan dalam bentuk kutipan tentang jumlah dokumen, tetapi yang dilaporkan merupakan hasil dari analilis dari dokumen tersebut. Adapun pada bagian tertentu yang dianggap kunci disajikan dalam kutipan utuh, untuk yang lainnya disajikan pokok atau intinya dalam rangkaian uraian hasil analilis kritis oleh peneliti.

\section{Teknik Keabsahan Data}

Teknik pemeriksaan keabsahan data di dalam penelitian ini tidak akan dilakukan melalui teori triangulasi. Triangulasi adalah pengecekan suatu kebenaran melalui cara mendapatkan data. Teknik pemeriksaan keabsahan data yang digunakan pada penelitian ini menggunakan trianggulasi teori, trianggulasi mencerminkan upaya untuk memahami fenomena yang dikaji (Maxwell, 1996: 93).

Teknik trianggulasi teori pemeriksaan kebenaran data hasil analilis dengan menggunakan teori yang berbeda tetapi membahas masalah yang sama. Peneliti menggunakan triangulasi teori. Triangulasi teori digunakan dengan cara memakai teori yang lain untuk membahas permasalahan kemudian dibuat kesimpulan. 


\section{Teknik Analilis Data}

Teknik analilis yang digunakan pada penelitian ini berupa analilis strukturalisme berupa unsur intrinsik. Teknik analilis struktural bersifat interaktif yang terdiri dari empat bagian, yakni pengumpulan data, reduksi data, penyajian data, dan kesimpulan.

1. Pengumpulan data

Pengumpulan data merupakan proses awal dari penelitian, yakni dengan mengumpulkan data serinci dan seakurat mungkin. Pengumpulan data dilakukan dengan teknik analilis data. Data yang digunakan berbentuk dokumen. Dokumen dalam penelitian ini adalah novel Hayya karya Helvy Tiana Rosa dan Benny Arnas.

2. Reduksi data

Reduksi data merupakan proses pengabstrakan, pemusatan, pemilihan, penyederhanaan, dan transformasi data yang hadir dari data yang didapatkan dari sumber data penelitian. Data yang diperoleh dalam dokumen tidak semua harus diambil, namun direduksi lebih dulu agar data lebih sederhana. Data yang tidak kurang atau tidak mendukung sebaiknya dibuang sehingga data menjadi lebih jelas dan fokus.

3. Penyajian data

Penyajian data berdasarkan pada rumusan masalah yang sudah dibentuk sebagai pertanyaan penelitian sehingga yang disajikan dan dipaparkan merupakan deskripsi mengenai keadaan dan kondisi yang rinci untuk menjawab dan menceritakan permasalahan yang terjadi.

4. Penarikan simpulan

Pada tahap inilah, data disimpulkan setelah melalui proses sajian data dan reduksi. Penarikan simpulan adalah jawaban dari permasalahan yang dibahas pada penelitian. Penarikan simpulan berlandaskan pada seluruh proses analisis data. Simpulan yang sudah diperoleh, diverifikasi lagi untuk mendapatkan hasil penelitian yang bisa dipertanggung jawabkan.

Penjelasan tentang teknik analilis data di atas digambarkan dalam bagan berikut:

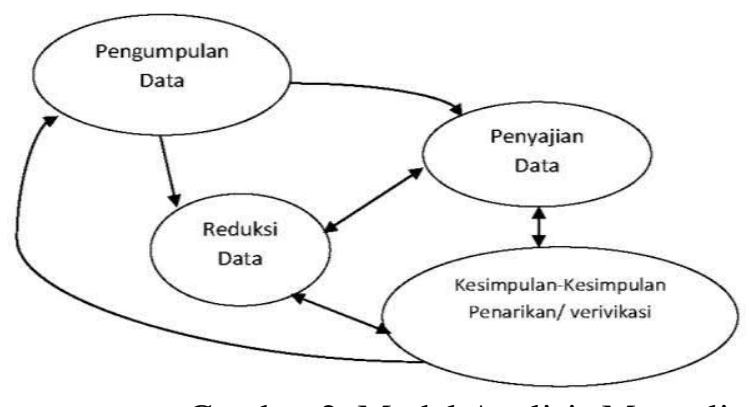

Gambar 2. Model Analisis Mengalir

(Miles, Mattew B. \& Huberman, A. Michael, 1992: 18)

\section{HASIL DAN PEMBAHASAN}

Di dalam penelitian ini untuk kajian struktural peneliti menyepakati untuk menganalisis kajian struktural dari Nurgiyantoro yang terdiri dari unur instrinsik, yang meliputi : 1) tema; 2) alur; 3) latar; 4) tokoh dan penokohan/ perwatakan; dan; 5) sudut pandang ( point of view). Dengan tujuan menekankan pada penelitian sastra seperti atau kalimat-kalimat dalam wacana analisis kata-kata dalam kalimat atau lebih besar lagi konteksnya. 
Selanjutnya kajian nilai-nilai pendidikan terkait nilai pendidikan yang merupakan segala sesuatu yang baik atau buruk, berguna bagi manusia dan bisa didapatkan dalam pembelajaran. Berkaitan dengan eksistensi manusia, nilai-nilai pendidikan menggunakan teori Lickona diantaranya berupa: 1) Nilai Pendidikan Religius, 2) Nilai Pendidikan Sosial, 3) Nilai Pendidikan Budaya, dan 4) Pendidikan Karakter.

\section{NOVEL}

Dunia kesusasteraan mengenal prosa sebagai salah satu genre sastra. Untuk memperjelas keberadaan jenis prosa, ia sering di dibandingkan dengan jenis prosa yang lain seperti puisi, walaupun perbedaan itu hanya secara teori. Akan tetapi dari prosa dan puisi akan lebih mudah dikenali sebagai karya sastra hanya dengan mengenal konvensi penulisannya.

Prosa dalam dunia sastra dapat disebut wacana naratif (narrative discource) dalam pendekatan semiotik dan struktural atau teks naratif (narative teks) fiksi (fiction). Istilah lain untuk fiksi ialah ceritaa rekaan atau cerita khayalan. Menurut Abrams (dalam Nurgiyantoro, 2012: 2) fiksi adalah sebuah karya naratif yang isi di dalamnya tidak menyasar pada kebenaran suatu sejarah. Istilah dari fiksi ini sering dipergunakan dalam pertentangan dan realitas (sesuatu yang terjadi dan benar) sehingga kebenarannya dapat dibuktikan dengan data empris. Ada atau tidaknya tidak perlu dibuktikan dengan angka dan data yang empiris.

Itulah yang membedakan sebuah karya fiksi dan non fiksi. Tokoh dalam cerita, peristiwa atau kejadian, dan tempat yang disebut didalam fiksi merupakan imajinatif, sedangkan karya non fiksi berarti bersifat faktual. Pendapat lain dijelaskan oleh Altenbenerd dan Lewis (dalam Nurgiyantoro, 2012: 2-3) prosa naratif walaupun bersifat imajinatif tetapi biasanya mengandung kebenaran yang mendramatiskan hubungan antar manusia dan pasti masuk akal. Hal tersebut diungkapkan berdasarkan pengalamannya. Pengalamannya tentu dilakukan secara selektif dan tentu saja bersifat subjektif.

Northrop Frye (dalam Waluyo, 1994: 3) istilah fiksi dapat diklasifikasikan menjadi beberapa yaitu 1) novel, novel realistik dan novel gaya; 2) bentuk otobiografi; 3) anatomi; dan 4) romansa prosa. Adapun Dorothy Eagle (dalam Waluyo, 1994: 2) membacakan fiksi erat kaitannya dengan novel, yakni semua cerita rekaan. Adapun kesusasteraan lama, novel/ novelet, roman dan cerita pendek dalam sastra modern baginya ialah karya fiksi.

Fiksi menyasar pada prosa naratif seperti novel dan cerpen, bahkan bisa dianggap sinonim dari novel. Novel sebagai karya sastra yang berisi imajinatif, kehidupan yang diidealkan dan diinginkan, dibangun oleh beberapa unsur pembangun atau unsur intrinsik seperti plot, peristiwa, latar, alur, penokohan, tokoh dan lain-lain. Sifatnya pun noneksistensial karena pengarang sengaja mengkreasikan. Tetapi ada pula karya sastra yang mendasar pada fakta (fiksi nonfiksi), seperti fiksi biografis (biographical fiction) apabila yang menjadi dasar adalah fakta biografis, fiksi historis (historical fiction), apabila yang menjadi dasar adalah sejarah, dan fiksi sains (science fiction) apabila yang menjadi dasar adalah ilmu pengetahuan.

Novel berasal dari bahasa Inggris "Novel" dan cerita pendek "short story" merupakan karya dengan dua bentuk sastra yang sekaligus disebut fiksi. Novel yang berasal dari bahasa Itali novella, secara harfiah novella ialah sesuatu yang baru, kecil kemudian diartikan menjadi bentuk prosa berupa cerita Abrams (dalam Nurgiyantoro, 2012: 9). Novel berarti mengandung pengertian cerita yang mengikat dengan adanya sifat saling berkaitan antar bagian.

Waluyo (1994: 37-38) mengungkapkan bahwa novel berasal dari bahasa latin novellus lalu disederhanakan menjadi novies yang memiliki arti baru. Disebut baru karena genre cerita fiksi ini muncul akhir dibandingkan roman dan cerita pendek. Novel muncul karena pengaruh filsafat dari John Lock yang menekankan pentingnya pengalaman dan fakta dan menganggap berfikir fantastis adalah sesuatu yang ada resikonya. Suasana yang digunkan dalam novel adalah realistis dan masuk akal. Didalam novel menurutnya terdapat 1) sebuah perubahan nasib dari tokoh dalam sebuah cerita; 2) biasanya tokoh utama tidak akan 
mati; dan 3) beberapa episode dalam kehidupan akan dilalui si tokoh. Unsur-unsur pembangun dari dalam atau unsur intrinsik sebuah novel seperti tokoh, tema, plot, alur, latar, sudut pandang, penokohan yang bersifat rinci dan kompleks dari pada unsur-unsur cerpen.

Jadi, novel adalah suatu karya sastra dalam bentuk prosa pendek, tetapi juga panjang yang mengandung estetika, dan saling berkaitan antar bagian (unsur), bersifat fiksi dan imajinatif. Kebenaran dalam novel tidak harus dibuktikan.

\section{KAJIAN STRUKTURAL}

Di dalam kajian struktural banyak dari para ahli yang memiliki pendapat berbeda, menyebutkan beberapa unsur yang ada di dalamnya dan tentu berbeda jumlahnya. Seperti kajian struktural menurut Esten (2013: 25) Hakekat cerita rekaan adalah bercerita, ada penceritaan dan yang diceritakan. Cara penceritaan inilah yang disebut pula sebagai struktur dalam cerita, diantaranya ialah : 1) alur; 2) latar; 3) penokohan/ perwatakan; 4) gaya bahasa dan; 5) pusat pengisahan ( point of view).

Selanjutnya menurut Waluyo (1994: 135) unsur yang membangun sebuah struktur yang memiliki sifat fungsional artinya diciptakan oleh penulis atau pengarang untuk mendukung maksud dan tujuan didalam cerita, maknanya ditentukan oleh keseluruhan dan kelengkapan cerita tersebut.

Adapun unsur pembangun menurut W. H Hudson adalah 1) plot; 2) dialog dan karakteristik; 3) pelaku; 4) gaya penceritaan (style); 5) setting; 6) filsafat hidup pengarang. Menurut Mochtar Lubis menyebutkan 7 unsur fiksi yakni: 1) tema; 2) plot; 3) character and deleneation; 4) suspence and foreshadowing; 6) immediacy and atmosphere; 7) limited focus and unity.

Selanjutnya pendapat Luxembung, dkk (1986: 36-37) keterkaitan tetap antara gejala yang berkelompok itulah yang disebut struktur. Keterkaitan tersebut diciptakan oleh peneliti sesuai dengan observasi yang dilakukannya. Contohnya: tokoh utama yang memiliki kaitan dengan lawan bisa berupa asosiasi (dukungan, bantuan, dan kepentingan bersama) atau lawan hubungan oposisi. Hubungan itulah yang dikatakan tetap, tidak bergantung pada sebuah karya tertentu khususnya novel.

Kemudian menurut Kurniawan (2001: 40) menjelaskan jika dilihat secara umum strukturalisme merupakan memandang dunia secara terstruktur hal ini merupakan suatu paham filsafat. Peran linguistik Saussurean sangat besar karena linguistis Saussurean memperkenalkan sebuah sistem. Strukturalisme memandang dunia sebagai sesuatu yang tertib, yang mengandung jaringan dan relasi. Adapun tujuan umum dari strukturalisme dan lingustik moderen Saussurean yang pada intinya memiliki kesamaan dengan para strukturalis.

Menurut Endraswara (2013: 49-50) strukturalis merupakan cara berfikir tentang berhubungan dengan diskripsi struktur-struktur dan tanggapan. Hal inilah yang menjadikan karya dari sastra memiliki keterkaitan satu dengan yang lain. Strukturlaisme ini juga dikatakan sebagai paham filsafat yang memosisikan dunia sebagai realistas berstruktur. Dunia yang dianggap hal yang tertib sebagai suatu keharusan dan sebuah relasi, karena relasi inilah yang dikatakan bersifat otonom. Atas dasar bahasa karya sastra dibangun tentu memiliki ciri dan bentuk atau makna yang otonom. Maksudnya pemahaman suatu karya sastra dapat dilihat dan diteliti dari teks sastra itu sendiri. Hanya saja harus tetap dikaitakan pada unsur pembangun karya sastra. Ide dasar strukturalis ialah tidak menerima golongan mimetik (karya sastra yang dianggap sebagai tiruan), melawan asumsi bahwa melalui karya sastra sebagai media komunikasi antara pembaca dengan pengarang, dan teori ekspresif (yang menganggap karya sastra sebagai ungkapan watak dan perasaan dari seorang pengarang/ penulis). Intinya, strukturalisme memfokuskan dan menekankan pada otonomi penelitian sastra.

Kajian struktural pada dasarnya dipelopori oleh teori saussure, yang mengubah diakronik menjadi sinkronik dari studi lingustik. Menurut para ahli strukturalisme apabila dibangun secara koherensif maka 
akan menjadi totalitas dari berbagai unsur pembangun maka disebut oleh karya sastra (Nurgiyantoro, 2012: 36). Sasaran pengertian karya sastra ada kaitannya dengan hubungan antar unsur (intrinsik) yang memiliki saling mempengaruhi, sifat saling menentukan, bersifat timbal balik, secara bersamaan mereka akan membentuk satu kesatuan yang utuh. Adapun unsur yang terdapat dalam teori Nurgiyantoro ialah tema, tokoh dan penokohan, latar, alur, dan sudut pandang.

Hal-hal yang dapat dilakukan untuk menganalisis karya sastra secara struktural ialah dengan mengidentifikasi terleih dahulu kemudian mendeskripsikan dan mengkaji fungsi hubungan antar unsur intrinsik fiksi yang saling berkaitan. Tetapi ada yang lebih penting ialah kontribusi apa yang diberikan terhadap tujuan estetik, menunjukan hubungan antar unsur dan makna keseluruhan yang ingin digapai.

Adapun Brooks ikut berpendapat bahwa ada 7 unsur pembangun cerita fiksi; 1) selektivitas; 2) titik pusat; 3) gaya bercerita; 4) penanjakan cerita; 5) konflik; 6) point of view dan; 7) movement/ gerakan.

Sedangkan Hartoko menyebutkan ada 4 unsur pembangun yaitu: 1) cerita; 2) alur; 3) hubungan antar peristiwa; 4) peristiwa acuan. Menurut Hartoko\& Rahmanto (dalam Nurgiyantoro, 2012: 38) kajian struktural dapat berupa analisis yang menyasar pada hubungan beberapa unsur dalam satu keseluruhan, mikroteks, dan relasi mikroteks itu. Seperti, menganalisis kalimat-kalimat dalam wacana atau kata-kata dalam kalimat atau atau yang lebih besar lagi konteksnya.

Membangun sebuah keutuhan makna yang memenuhi standar ilmu dapat melalui hubungan perangkat struktur sastra agar lebih optimal. Ada dua konsep didalam penelitian sastra, yaitu: konsep defamiliarisasi (konteks sastra asing atau aneh) dan deotomatisasi (menggunakan bahasa yang spesifik). Hal terpenting para pengkaji struktural ialah fokus meneliti aspek-aspek penyulapan (daya juang atau proses estetika untuk membungkus kenyataan menjadi imajinatif dan menarik) atau pengasingan dari material sastra menjadi kreasi sastra yang unik.

Menurut Hawkes (dalam Endraswara, 2013: 50-51) strukturalisme memiliki tiga pokok. Pertama, kesesluruhan dalam gagasan. Kedua, gagasan transformasi. Dan ketiga, gagasan yang teratur dan mandiri. Kehadiran strukturalisme dinamis dan telah mengalami evolusi yang tidak singkat. Hingga sampai saat ini pengkajian menggunakan strukturalisme digunakan oleh beberapa penelitian karena tanpa terjun di lapangan. Cukup memfokuskan pada objek yang akan dikaji misalnya, novel, cerpen, dan karya sastra yang lainnya.

Jadi, dari berbagai pendapat dan paparan para ahli dapat diambil kesimpulan bahwa kajian struktural merupakan serangkaian analilis yang melibatkan unsur pembangun intrinsik. Unsur-unsur tersebut meliputi : 1) Tema; 2) Tokoh dan Penokohan; 3) Latar; 4) Alur; 5) dan Sudut pandang. Peneliti sepakat dengan teori dari Nurgiyantoro. Dengan tujuan menekankan pada penelitian sastra seperti atau kalimat-kalimat dalam wacana analisis kata-kata dalam kalimat atau lebih besar lagi konteksnya.

\section{Tema}

Novel Hayya karya Helvy Tiana Rosa dan Benny Arnas merupakan novel yang dipusatkan pada seorang tokoh utama atau lakon, dalam dalam klasifikasi lain juga sebagai novel percintaan karena melibatkan peranan tokoh pria dan wanita.

Tema yang merupakan ide mendasar suatu karya oleh pengarang. Penyebutan lain dari tema yaitu ide, pandangan hidup pengarang yang melatar belakangi suatu karya tercipta, dan gagasan. Tema pula yang menjadi awal pembentukan suatu karya. Hal inilah yang menjadikan tema salah satu unsur instrinsik novel Hayya Karya Helvy Tiana Rosa dan Benny Arnas. Novel tersebut mengandung tema perjuangan seorang Rahmat dalam menjaga Hayya, anak kecil asal Palestina.

Ketika Hayya memutuskan untuk masuk koper Rahmat agar bisa bersama Rahmat, dan Rahmat sangat bahagia atas hal itu. Bagi Rahmat menjaga Hayya adalah prioritasnya kini. Ia sudah terlalu sayang pada 
Hayya. Hingga suatu ketika orang-orang salah paham, mengatakan bahwa Rahmat telah memiliki anak bersama Ria, pengasuh Hayya. Hal tersebut dapat dilihat dari kutipan berikut:

"Kami sudah mendengar semuanya dari Ria dan Adin." Bi Nurul buka suara. "Bibi minta maaf kepada Rahmat karena sudah gegabah menuduhmu yang bukan-bukan."

"Iya kang, Abrar juga minta maaf. Abrar juga sudah bicara kasar pada Akang tadi." Rahmat mengamit bibirnya hingga membentuk garis. Sementara Hayya dalam gendongannya memeluk Rahmat makin erat. Matanya mendadak hangat.

"Yasna juga minta maaf, Kang. Yasna benar-benar tak enak hati. Yasna malu menjadi calon istri yang tidak peka." Yasna lebih banyak menundukkan wajah karena perasaan bersalah yang mengerubunginya.

"Nggak, apa-apa," ujar Rahmat tennag. "Rahmat maklum kok. Sekarang, Rahmat minta kita semua menjaga Hayya." Rahmat mengelus-elus rambut Hayya. "Kondisinya benar-benar rapuh. Dia butuh figur orang tua yang bisa ia percayai sekaligus bisa ia dengarkan kata-katanya. Rahmat izin tetap berada di kamar ini bersama Hayya disini sampai Abah siuman" (Hayya, 2019: 188).

Kutipan lain yang menunjukkan betapa Rahmat ingin menjaga Hayya adalah:

“Oh lu mulai, lu mulai menyeberang pulau nih?” Rahmat memandang Adin dengan geram. "Lu nggak mau bersama gue nyelamatin Hayya ya?"

"Nyelametin Hayya bagaimana, Kang?" tiba-tiba terdengar suara dari arah dapur. Seorang gadis berkerudung berjalan menuju mereka.

"Yasna?" Rahmat tercekat.

Yasna mengambil tempat duduk di samping Bi Nurul. "Akang jamin Hayya akan lebih bahagia sama Akang, sama kita, dibanding di Tanah Air-nya di Palestina sana?"

"Bukankah sudah Adin jelaskan kalau Hayya sendiri yang bersembunyi di dalam koper. Artinya apalagi kalau bukan karena dia merasa nyaman dan bahagia dengan Akang. Artinya...dia juga tahu kalau Akang sangat menyayanginya, Yasna."

"Akang yakin anak seumuran dia sudah bisa memilih jalan hidupnya sendiri?"

Hening.

"Akang yakin?" desak Yasna.

"Justru keputusan gadis kecil yang masih belum berdosa seperti Hayya itu berasal dari hati kecilnya yang paling polos dan jujur, tidak dikotori oleh hal-hal lain yang bisa menodainya. Hayya masih suci, Yasna," dalih Rahmat.

"Akang tidak bisa mencampur-adukkan kepolosan seorang anak dengan kematangannya dalam menentukan jalan hidup! Itu dua hal yang berbeda, bahkan sangat bertolak belakang. Bagaimanapun, sebagaimana anak kecil, fitrahnya masih polos. Masih suci. Nah kenapa kepolosan itu tidak Akang angkat ke permukaan terkait keputusan untuk masa depannya?"

"Oleh karena itu ia membutuhkan arahan, Yasna. Ia membutuhkan orang tua."

"kenapa tidak menjadi orang tuanya dengan cara sebagaimana mestinya?"

"Hayya kadung disebut hilang dan diculik!"

"Jadi Akang mengakui kekeliruan Akang dan oleh karenanya, karena terlanjur basah, Akang mau mandi sekalian di kolam kesalahan yang sudah Akang buat?"

Rahmat mendongak. Ia tak terima dengan tuduhan calon istrinya.

"Dan atas semua nafsu dan gengsi itu, Hayya Akang jadikan perisai dan pembenaran? Percayalah, Kang, kita salah. Akang keliru. Mari kita hadapi bersama."

"Rasanya Rahmat perlu menyampaikan kalimat penutup malam ini. Rahmat sangat mencintai Hayya. Tak ada kompromi bagi mereka yang ingin memisahkan Hayya dari saya. Palestina hari ini, bukan tanah yang menjamin ia bisa hidup lebih baik dibandingkan bersama Rahmat . tentang adopsi yang prosedural itu, 
mungkin semuanya benar. Tapi untuk Hayya, itu semua adalah teori!" lalu Rahmat meninggalkan ruangan keluarga.

(Hayya, 2019: 208-211).

Kalau tidak karena hatimu yang putih bersih, tentu belum tentu pula engkau akan tiba disini, bidadariku dari jauh; Hayya Qasim binti Atta Hisyam (Hayya, 2019: 97).

Kutipan diatas merupakan bentuk usaha Rahmat dalam menjaga Hayya, meskipun sekuat apapun Rahmat menjaga Hayya tetapi jika cara yang ia gunakan tidak sesuai aturan akan bukan tidak mungkin dirinya akan menimbulkan permasalahan baru. Pertentangan itu tidak hanya dari keluarganya melainkan dari pihak kantor, tempat ia bekerja dan pastinya relawan kemanusiaan, Hubbu.

Demikian pula yang menunjukkan perjuangan Rahmat menghalalkan Yasna. Hal tersebut dibuktikan pada kutipan berikut:

"Sabar, sodara-sodara!" ujar Rahmat dengan senyum lebar dan air muka yang sedikit pun tak menunjukkan rasa bersalah. "Momen ini sudah lama direncanakan, jadi... ya, formasinya harus lengkap supaya afdol. Bukan begitu, ukhti Yasna?" Rahmat menyunggingkan senyum pada calon istrinya itu.

Yasna tersipu malu. Kedua orang tuannya hanya melihat ke arah Yasna dengan air mata semringah, meskipun mereka sendiri sebenarnya tidak mengerti maksud mereka dikumpulkan seperti ini (Hayya, 2019: 196).

Rahmat menatap sekeliling. Bi Nurul Antusias. Abrar tegang. Ria dan Adin kompak menatap Rahmat. Abah melilitkan syal hingga menutupi leher. Yasna tegang. Kedua orang tua Yasna seperti tertular anaknya, ikutikutan tegang.

"Ukhti, Yasna, mohon kiranya bersedia maju beberapa langkah ke tengah lingkaran." Nada suara Rahmat dibuat sedemikian rupa sehingga terdengar seperti pangeran dalam kisah-kisah dongeng yang sedang merayu calon istrinya.

Yasna mematung, sebelum bangkit dan mengikuti instruksi Rahmat ketika Bi Nurul memberi kode untuk bergegas.

Kini Rahmat dan Yasna sudah berhadapan dalam jarak dua langkah orang dewasa tanpa melihat satu sama lain.

Hening.

Semua menanti.

Abah batuk sekali.

Tiba-tiba Rahmat membungkuk dan menyerahkan sebuah kotak di tangan

kanannya yang terbuka.

"Terimalah ini, wahai calon istriku," Rahmat benar-benar menjelma pujangga.

"Pangeran sejati takkan ingkar janji."(Hayya, 2019: 197).

Rahmat membuktikan kesungguhan cintanya dengan mengkhitbah Yasna, perempuan yang sedari dulu telah memiliki ruang di hati Rahmat. Selepas dari Palestina untuk menjadi relawan kemanusiaan, Rahmat benar-benar menepati janjinya untuk melamar dan menikahi Yasna dengan disaksikan banyak orang.

\section{Tokoh dan Penokohan}

Tokoh merupakan orang atau pelaku yang dimunculkan dan mengalami peristiwa dalam karya fiksi. Sedangkan penokohan adalah cara pengarang dalam menggambarkan karakter tokoh dalam cerita, baik lahir maupun batinnya. Di dalam tokoh dan penokohan terdapat tokoh utama yang selalu muncul dalam percakapan atau diceritakan langsung oleh pengarang, tokoh baik dan jahat, tokoh penengah atau tambahan yang kesemuanya memiliki tugas masing-masing dalam penokohan di dalam novel. 
Tokoh dan penokohan di dalam novel Hayya karya Helvy Tiana Rosa dan Benny Arnas diejalaskan pengarang dengan beberapa cara, seperti: apa yang diucapkan tokoh, jalan pikiran tokoh, ciri-ciri fisik tokoh, analilis pengarang, pengakuan tokoh yang satu atas tokoh yang lain, dan perbuatan atau tingkah laku tokoh. Selanjutnya analilis tokoh dalam novel tersebut akan dibatasi pada tokoh yang sering muncul dan memiliki peranan cukup penting dalam cerita. Adapun tohoh dan penokohan dalam novel tersebut adalah: Hayya

Hayya merupakan tokoh utama dan termasuk tokoh protagonis, ia memiliki sifat penurut. Setelah ia menjadi yatim piatu di usianya yang masih sangat kecil membuatnya selalu murung. Seolah Hayya lupa bagaimana caranya tersenyum, hingga ia bertemu Rahmat yang merupakan salah satu relawan kemanusiaan. Hayya memiliki karakter yang baik, ia selalu menurut terhadap Rahmat. Hayya diceritakan langsung, bahwa ia memiliki sifat penurut. Hal tersebut dibuktikan oleh kutipan:

Dua puluh menit yang lalu Adin tau kalau ada yang tidak beres. Sebelum ketukan pintu yang terdengar agak serampangan itu singgah di gendang telinganya, derap langkah orang-orang di kejauhan yang makin lama makin dekat, membuatnya bergegas mengambil kain gendongan dan menaruh Hayya di dalamnya. Gadis lima tahun itu seperti selalu percaya dengan apa yang Adin lakukan, menurut saja (Hayya. 2019: 12).

\section{Rahmat} berikut:

Rahmat adalah tokoh utama, termasuk tokoh protagonis. Rahmat memiliki beberapa karakter sebagai

\section{Penyayang}

Sejak kepergian adiknya untuk selamanya, Rahmat terbebani perasaan bersalah dan kekosongan. Hingga ia bertemu dengan Hayya dan langsung menyayangi Hayya. Ia seperti menemukan kembali sosok adiknya yang sudah tiada. Sifat penyayang dari Rahmat dibuktikan melalui kutipan berikut:

Seakan-akan baru menyadari hal itu, Rahmat lekas mengangkatnya ke atas sofa "Tunggu ya, om ambilkan air putih dan..." (Hayya, 2019: 97).

Usai memberinya minum, Rahmat membawa gadis kecil itu ke kamar tamu yang biasa ditempati Adin. Gadis kecil itu menurut saja. ia berbaring. Rahmat tiba-tiba merasa sangat kasihan padanya. Oh, Allah terima kasih telah menyelamatkan gadis kecil dengan mata paling indah yang pernah kutemui.. terma kasih telah menyelamatkan Hayya (Hayya, 2019: 97).

\section{Keras Kepala}

Watak dari sang ayah diwarisi oleh Rahmat, ia memiliki sifat keras kepala. Jika dulu sifat keras kepala yang dimilikinya untuk menentang agama kini sifat keras kepala itu digunakan untuk sesuatu yang baik, sifat Rahmat tersebut dibuktikan melalui kutipan berikut:

Rahmat, bagaimanapun, hati kecilmu menyuarakan sesuatu yang seharusnya kau ikuti. Bukankah selama ini kau selalu mempercayainya? Tetapi bagaimana kalau Hayya memang lebih baik berada bersama Gue? Gue bisa jadi kakak, om, atau bahkan orangtua yang baik untuk gadis yatim piatu itu kok. Sifat keras kepalanya tiba-tiba muncul kembali, menentang sesuatu yang ia mohonkan dalam doanya (Hayya, 2019: 99).

"Gue memang sayang Hayya." Suara Rahmat terdengar berat, tapi santai (Hayya, 2019: 124).

\section{Humoris}

Meskipun penampilan, dan gaya bicara Rahmat kaku ia tetap memiliki sifat humoris, dibuktikan melalui kutipan:

"Kawinan kawinan!" sambar Rahmat dengan ekspresi menahan tawa. "Kambing kali kawinan. Nikah oi nikah!" Adin tertawa (Hayya, 2019: 115). 


\section{Romantis}

Rahmat memiliki sisi romantis, meski ia dinilai bijaksana, berwibawa dan kaku tetapi ia juga memiliki sifat romantis terhadap Yasna. Sifat romantis Rahmat, dibuktikan melalui kutipan berikut:

"Sabar, sodara-sodara!" ujar Rahmat dengan senyum lebar dan air muka yang sedikit pun tak menunjukkan rasa bersalah. "Momen ini sudah lama direncanakan, jadi... ya, formasinya harus lengkap supaya afdol. Bukan begitu, ukhti Yasna?" Rahmat menyunggingkan senyum pada calon istrinya itu. Yasna tersipu malu. Kedua orang tuannya hanya melihat ke arah Yasna dengan air mata semringah, meskipun mereka sendiri sebenarnya tidak mengerti maksud mereka dikumpulkan seperti ini. (Hayya, 2019: 196).

Rahmat menatap sekeliling. Bi Nurul Antusias. Abrar tegang. Ria dan Adin kompak menatap Rahmat. Abah melilitkan syal hingga menutupi leher. Yasna tegang. Kedua orang tua Yasna seperti tertular anaknya, ikutikutan tegang. "Ukhti, Yasna, mohon kiranya bersedia maju beberapa langkah ke tengah lingkaran." Nada suara Rahmat dibuat sedemikian rupa sehingga terdengar seperti pangeran dalam kisah-kisah dongeng yang sedang merayu calon istrinya. Yasna mematung, sebelum bangkit dan mengikuti instruksi Rahmat ketika Bi Nurul memberi kode untuk bergegas. Kini Rahmat dan Yasna sudah berhadapan dalam jarak dua langkah orang dewasa tanpa melihat satu sama lain. Hening. Semua menanti. Abah batuk sekali.

Tiba-tiba Rahmat membungkuk dan menyerahkan sebuah kotak di tangan kanannya yang terbuka.

"Terimalah ini, wahai calon istriku," Rahmat benar-benar menjelma pujangga. "Pangeran sejati takkan ingkar janji." (Hayya, 2019: 197).

"Ya sambil menunggu Hayya, dan kelak anak-anak yang lahir dari rahim bidadariku ini.." lirih rahmat (Hayya, 2019: 259).

Kedua pasangan tersebut memilih Palestina sebagai daerah tujuan bulan madu, yang awalnya ditentang semua orang yang mendengarnya. Palestina? Bulan madu?

Tapi ini bukan sekedar bulan madu.

Yasna dan Rahmat terus saling menatap.

Tersenyum.

Bergengaman tangan dengan mata yang masih kaca (Hayya, 2019: 260).

\section{Bijaksana}

Rahmat juga memiliki sifat yang bijak, meski dengan sahabatnya yang dalam keseharian tidak terlepas dari candaan. Sikap bijaksana diakui oleh Adin, yang seringkali dikatakan oleh sahabatnya. Hal ini dibuktikan melalui kutipan berikut:

"Semua manusia punya hak untuk hidup. Untuk mencari tempat dan sumber kegembiraan yang lebih baik." (Hayya, 2019: 122).

\section{Adin}

Adin adalah tokoh tambahan. Adin merupakan sahabat Rahmat, mereka sama-sama seorang jurnalis. Meski penampilan Adin berambut panjang dan berjenggot tebal, tetapi ia tetap gaul. Adin memiliki karakter humoris, dibuktikan melalui kutipan: 
"Pait...pait..pait!" umpat Adin seraya bangkit dari duduknya. "Dosa apa gue ampe ketemu anjing-anjing galak kayak gini!" meskipun sebagaian besar ditutupi berewok dan rambut panjang keritingnya yang mengembang, ekspresi terperangah tak bisa ia sembunyikan (Hayya, 2019: 16).

"Brengsek lu, Mat! Gara-gara lu, gua masuk sarang genderuwo nih! Umpatnya dalam hati (Hayya, 2019: 17).

Adin terenyak. Benar-benar terenyak ketika ketiga banci itu kini menyerbunya. Ia tak punya pilihan lain selain meladeni mereka. Mereka bergulat. Tak imbang memang, namun sedikit bekal bela diri yang Adin miliki (tentu saja plus ego sebagai laki-laki sejati\} membuatnya tak mau kalah. Tak menunggu lama, lima menit kemudian, mereka bertiga sudah menjadi tiga tali kusut yang mengunci satu sama lain. Kedua ketiak Adin menindih dua kepala dan kedua ujung kakinya mengapit sebuah kepala (Hayya, 2019: 17-18).

“Atau... jangan-jangan kamu fansya Upin-ipin? Tebak Adin dengan muka serius (Hayya, 2019: 152).

"Ya, Allah," Adin mengurut-urut dada. "memang saraf lu, ya"

“Sarap?” Ria mengernyitkan dahi.

"Iya, saraf. Mungkin lu belum sarafan tadi pagi." (Hayya, 2019: 157).

\section{Ria}

Ria adalah tokoh tambahan, ia termasuk tokoh protagonis. Ria, yang berkewarganegaraan Malaysia itu memiliki beberapa sifat yang dijelaskan sebagai berikut:

\section{Humoris}

Sifat Ria yang kerap ditunjukan masih seperti anak-anak tetapi sering membuat Adin dan Rahmat yang kesal sekaligus terhibur. Sifat humoris Ria dibuktikan oleh kutipan berikut:

"Jadi saye ni nak kalian pekerjakan untuk mengasuh anak kalian? Hiii." Ria bergidik membayangkan katakatanya sendiri (Hayya, 2019: 154).

"Ya adalah. Rupe macam Pakcik boleh jadi penculik, penjahat, bandit, walaupun juga boleh mirip rocker, yeaccch!" cerocos Ria yang cepat sekali mengubah mood kalimatnya, dari menakutkan menjadi ngacol diujungnya

"Ya Allah,” Adin mengurut-urut dada. "Memang saraf lu, ya?" (Hayya, 2019: 157).

\section{Penyayang}

Ria yang merupakan pengasuh dari gads kecil Palestina yang bernama Hayya itu memiliki sifat penyayang. Hal tersebut dibuktikan oleh kutipan sebagai berikut:

"Bangun tidur tampaknya. Oh, jam berapa ni?" Ria melihat ke sekeliling, berharap menemukan jam dinding. "Dah waktunya mandi petang nih. Ayo kita mandi, Budak Cantik." (Hayya, 2019: 155).

\section{Yasna}

Yasna adalah tokoh tambahan, ia termasuk tokoh protagonis. Yasna adalah perempuan yang dicintai Rahmat, ia memiliki sifat pencemburu, dibuktikan oleh kutipan berikut:

Tak lama, dengan wajah yang berlinang air mata, Yasna datang dengan segelas air putih hangat. "Kasih ini Brar, kalau Abah sudah siuman." Yasna menoleh ke arah Rahmat sebentar dengan tatapan benci campur tak mengerti, sebelum meletakan gelas itu di atas meja kecil di samping dipan (Hayya, 2019: 181).

Sikap Yasna berubah ketika Hayya memanggil Rahmat dengan sebutan abi dan memanggil Ria dengan sebutan umi. Yasna yang tidak tau kabar apapun tentang Rahmat bahkan sekalipun kebenarannya, terbakar 
api cemburu, kecewa, dan juga marah. Ia kecewa dengan Rahmat. Tetapi pada akhirnya Yasna merasa terlalu kekanak-kanakan dan sangat pencemburu karena menyimpulkan sesuatu yang belum tentu kebenarannya. Hal tersebut dibuktikan sebagai berikut:

"Yasna juga minta maaf, Kang. Yasna benar-benar tak enak hati. Yasna malu menjadi calon istri yang tidak peka." Yasna lebih banyak menundukkan wajah karena perasaan bersalah yang mengerubunginya (Hayya, 2019: 188).

\section{Abrar}

Tokoh Abrar sebagai tokoh pelengkap dalam novel Hayya. Abrar merupakan adik dari Yasna, ia juga dekat dengan Kyai Zainal (Ayahnya Rahmat). Ia diceritakan baik, paham ilmu agama dan hafal qur'an (hafizh). Adik Yasna ini yang memiliki sifat peka, dibuktikan oleh kutipan berikut:

"Hmmm.. Kang Rahmat kayaknya ada yang dipikirin." Ternyata Abrar masih menangkap ketidakberesan itu. "Kalau ada yang mengganjal, sampaikan saja, Kang biar sama-sama enak. Kan sebentar lagi hari bahagianya," kejar hafizh Quran itu (Hayya, 2019: 178).

\section{Abah/ Kyai Zainal}

Abah/ Kyai Zainal, sebagai tokoh pelengkap. Ia merupakan ayah dari Rahmat, seorang pemuka agama di Ciamis. Perannya besar di masyarakat. Ia disegani, dihormati, karena sifat dan perilakunya. Sifat bijaksana, dari tokoh ini dibuktikan oleh kutipan:

"Setelah ijab -kabul besok, saran Abah serahkanlah Hayya ke pihak berwajib. Kamu ceritakan saja yang sebenarnya kepada kepala rombonganmu di Palestina waktu itu. Jangan lupa meminta maaf karena kamu telah khilaf memanfaatkan keadaan itu." Kiai Zainal memberi saran (Hayya, 2019: 207).

\section{Bi Nurul}

Bi Nurul adalah bibi dari Yasna yang memiliki sifat baik, selain penyayang Bi Nurul juga memiliki sifat yang humoris. Ucapan Bi Nurul yang terkesan galak justru membuat orang mendengarnya justru tidak takut sebab terkesan lucu. Hal tersebut dibuktikan dari kutipan:

"Sekali lagi kamu merusak suasan, Bibi jadiin sambel kamu ya!" Bi Nurul memasang wajah sewot (Hayya, 2019: 195).

\section{Pak Wildan}

Pak Wildan adalah tim relawan kemanusiaan dari Hubbu, usianya diatas Rahmat. Ilmu agamanya bagus, beberapa kali pertanyaan dari Rahmat dan Adin berkitan agama khususnya selama di Palestin beliau jawab dengan santai dan tenang. Pak Wildan merupakan tokoh pelengkap. Pak Wildan memiliki beberapa sifat, hal tersebut digambarkan sebagai berikut:

\section{Lembut}

Sifat lembut yang dimiliki pak Wildan dibuktikan melalui kutipan berikut:

Laki-laki 45 tahun itu memberi pengertian tentang apa yang sebenarnya sedang dihadapi. Sebenarnya Adin keberatan dengan nasihat Pak Wildan sebab laki-laki bertutur lembut itu mengutarakannya kepada ia dan Rahmat.....(Hayya, 2019: 22).

\section{Mengalah}

Sifat lain dari Pak Wildan adalah mau mengalah meskipun usianya lebih tua dari pada Rahmat dan Adin, dibuktikan melalui kutipan berikut: 
"Begini," imbuhnya kemudian, ada nada mengalah dalam suaranya, "Ana akan kontak rekan di Hura, apakah keadaan memungkinkan kalau kita ke Bersyeba.”...(Hayya, 2019: 23).

\section{Ustadzah Khalida}

Ustadzah Khalida merupakan tim dari Hubbu, ia berasal dari negri Jiran, Malaysia. Ustadzah Khalida dikenal pandai membuat strategi. Ustadzah Khalida sebagai tokoh pelengkap yang memiliki sikap hebat. Sifat tersebut dibuktikan melalui kutipan berikut:

Adin mati kata, Rahmat tak berani membantah. Mereka tahu kalau perempuan paruh baya yang merupakan salah satu thinker Aman-Palestin itu bukan orang sembarangan. Meskipun perempuan, Khalida adalah pakar strategi dan jago lobi. Tak terhitung kali keberhasilannya meloloskan bala bantuan ke jantung Gaza dalam sejumlah misi yang pernah ia pimpin. Ia juga yang banyak membimbing NGO lebih baru seperti Hubbu (Hayya, 2019: 24).

\section{Latar}

Latar atau setting adalah tempat, waktu, dan suasana peristiwa dalam karya sastra, yang dalam hal ini novel Hayya karya Helvy Tiana Rosa dan Benny Arnas. Terdapat 3 jenis latar yaitu pertama berhubungan dengan tempat, kedua berhubungan dengan persitiwa yang terjadi, dan ketiga berhubungan dengan waktu dalam cerita. Adapun pemaparan latar dalam novel tersebut sebagai berikut:

\section{Berhubungan dengan tempat}

\section{Palestina}

Palestina adalah salah satu negeri yang ada di bumi Syam. Latar tempat Palestina sering dimunculkan penulis, melalui percakapan tokoh atau pun diceritakan langsung. Ketika Rahmat, Adin dan beberapa relawan dari Hubbu menjelajah bumi Syam. Hal ini dapat dilihat dari kutipan:

Mereka menjelajahi Kseifa, Ar'ara BaNegev dan Dimona, lanskapnya nyaris sama-berbatu, kering, berdebu, rumah dan bangunan yang tak lagi utuh, meskipun tak dapat dikatakan gersang (Hayya, 2019: 23).

Ternyata jarak Jordania-Palestina-Wilayah Taibe- tidak terlalu jauh (Hayya, 2019: 26).

Walaupun Adin dan Rahmat sudah tahu kalau wilayah Masjidil Aqsa berjarak tak sampai 80 kilometer dari jalur Gaza yang menjadi pusat konflik tiada henti....(Hayya, 2019: 29).

"Selain kita kudu bersyukur- bisa menginjakkan kaki di Palestina dan insya Allah beribadah di Aqsa terus kedepannya plus bisa napak tilas di tepi Barat, kenyataan itu menunjukkan kalau tak ada prediksi yang bisa dijadikan pegangan di bawah kobaran perang," (Hayya, 2019: 29).

\section{Malaysia}

Malaysia termasuk negara yang berada di Asia Tenggara. Malaysia memiliki ibu kota Kuala Lumpur. Malaysia inilah yang menjadi salah satu latar tempat didalam novel Hayya. Ketika program kemanusian sudah berakhir dan Rahmat kembali ke tanah air. Tetapi sebelumnya di bandara yang berada di Malaysia sebagai titik keberangkatan. Dibuktikan melalui kutipan:

Perjalanan kali kedua ini mengambil Kuala Lumpur sebagai titik keberangkatan (Hayya, 2019: 26).

\section{Ciamis}

Ciamis merupakan daerah yang ada di Jawa Barat. Ciamis merupakan latar tempat dalam novel, diceritakan merupakan kampung kelahiran Rahmat. Di Ciamislah abah tinggal, dan akan menjadi tujuan pulang kampung bagi Rahmat. Hal tersebut dibuktikan melalui kutipan berikut: 
Sedari tadi ia sebenarnya ingin sekali ikut nimbrung dan membantu Rahmat menjelaskan tujuan utama mereka ke Ciamis. Adin juga baru paham kalau kedatangan Rahmat ke Ciamis ini, bukan semata untuk mengamankan Hayya.....(Hayya, 2019: 177).

Dua jam kemudian, hampir semua saluran televisi menayangkan berita ditemukannya Hayya di Ciamis dalam keadaan sehat wal afiat (Hayya, 2019: 256).

\section{Jakarta}

Jakarta merupakan tempat dimana Rahmat tinggal dan bekerja sebagai jurnalis. Kepulangan Rahmat setelah mengikuti relawan kemanusiaan di Palestina diceritakan sempatan berhenti di Tanjung Priok tepatnya di Jakarta. Kepulangan Rahmat menggunakan kapal itu berhenti di Tanjung Priok, Jakarta. Hal tersebut dibuktikan melalui kutipan sebagai berikut:

Kapal kemanusiaan Aman-Palestin merapat di Pelabuhan Tnjung Priok. Seperti mengolok-olok perasaannya yang sendu dan kusut, langit Jakarta maam itu lebih gelap dari biasa....(Hayya, 2019: 74).

\section{Ruang tamu}

Ruang tamu yang beberapa kali disebutkan dalam novel merupakan ruang tamu di rumah Rahmat. Ia merasa ada keanehan di dalam rumahnya itu. Sehingga Rahmat yang terbilang pemberani itu mencari tahu apa yang sebenarnya terjadi di dalam ruang tamunya itu. Hal tersebut digambarkan dari kutipan berikut:

Rahmat beralih ke ruang tamu. Ia mengecek pintu. Aman terkunci... (Hayya, 2019: 83).

\section{Dapur}

Dapur merupakan tempat dimana Rahmat menemukan kejanggalan demi kejanggalan. Kejanggalan itulah yang pada akhirnya membuat Rahmat tergerak untuk mencari tahu, teka-teki keanehan bertambah didalam rumahnya yang terjadi di dapur. Di Dapur pula Rahmat merangkap menjadi ibu bagi Hayya, meskipun hanya memasak mie untuk Hayya. Hal tersebut diketahui oleh sahabatnya, Adin. Yang menjadi awal Adin mengetahui suatu rahasia besar dari Rahmat. Yakni, adanya Hayya ditengah-tengah mereka. Berikut beberapa kutipan yang menunjukkan latar tempat di dapur:

Bukan! Tapi teriakan melengking dari ketiga orang yang baru keluar dari pintu dapur rumah semi permanen itu ..... (Hayya, 2019: 15).

"Wah masak mi goreng nih di belakang!" teriak Adin tanpa menoleh. "Gue berkuah gitu tapi jangan kebanyakan!” Di dapur Rahmat hanya tersenyum. (Hayya, 2019: 120).

\section{Kamar mandi}

Kamar mandi yang dimaksud ialah kamar mandi rumah Rahmat yang berada di Jakarta. Sebab tempat inilah yang disebutkan dalam novel. Berikut kutipan dari novel:

Sekeluar dari kamar mandi, Rahmat mendapati ponselnya di dalam lemari pakaian berdering (Hayya, 2019: 61).

\section{Balkon}

Balkon yang menjadi tempat Rahmat dan Adin biasa nongkrong ialah balkon lantai 14 tempat berkantornya di Jakarta. Hal tersebut dibuktikan melalui kutipan sebagai berikut:

Di balkon lantai 14 gedung tempat berkantornya beberapa perusahaan itu, mereka memandang langit Jakarta yang monokrom (Hayya, 2019: 102). 


\section{Kantor}

Sebagai seorang Jurnalis, Rahmat termasuk orang perkantoran. Meski seorang jurnalis bukan berarti ia tidak ke kantor. Kantor yang menjadi tempat ia bekerja ialah Republika. hal tersebut diceritakan melalui kutipan berikut:

Tak lama setelah pak Wildan meninggalkan kantor Republika, Rahmat mengajak Adin menemaninya berbelanja (Hayya, 2019: 114).

\section{Mall}

Tinggal di kota metropolitan sudah tidak asing dengan pusat perbelanjaan yang biasa disebut mall oleh kebanyakan orang. Mall merupakan tempat dimana menjual berbagai barang selain menjadi tempat dimana orang-orang berbelanja kebutuhan, Mall juga menjadi tempat orang-orang kota nongkrong. Tujuan Rahmat datang ke Mall untuk membelikan keperluan Hayya selama di Indonesia, meski tidak secara langsung diceritakan oleh pengarang. Dari penggalan berikut menjadi salah satu bukti latar tempat yang terjadi di Mall:

Di lantai dua mall, Rahmat menelepon seseorang seraya menjauh...(Hayya, 2019: 116).

\section{Masjid Baitul Amin}

Masjid Baitul Amin merupakan nama masjid yang berada di daerah Ciamis, tempat tinggal Abah. Masjid Baitul Amin pula yang akan digunakan Rahmat untuk ijab qabul. Hal tersebut dibuktikan oleh kutipan sebagai berikut:

Langit Ciamis mendung pagi itu. Meskipun begitu, hujan tidak turun sepanjang perjalanan Rahmat dan rombongan ke Masjid Baitul Amin (Hayya, 2019: 239).

\section{Berhubungan dengan peristiwa}

\section{Was-was}

Was-was merupakan keadaan hati yang cemas bercampur takut. Entah karena hal baik atau hal buruk, perasaan ini pasti dirasakan setiap orang. Perasaan inilah yang diraskan Adin ketika menggendong Hayya, meski was-was ia tetap menenangkan Hayya dalam gendongnya. Perasaan was-was inilah di tunjukkan melalui kutipan dalam novel sebagai berikut:

Adin mengedarkan pandangan. Perasaannya was-was. (Hayya, 2019: 15).

\section{Serius}

Serius adalah kedaan seseorang yang sedang berkonsentrasi tinggi pada pembahasan maupun persoalan penting. Keadaan serius inilah yang seharusnya diterapkan pada hal-hal yang sensitif, penting, dan resmi. Adapun suasana ini dibuktikan melalui kutipan berikut ini:

"orang-orang Palestina sadar benar kalau Israel memasang mata dan telinga di mana-mana. Entah siapa yang memulai, tapi kata pak Wildan, semuanya diawali semacam seruan dan pemberitahuan berantai gitu, bahwa percakapan di ruang publik seminim mungkin menyentuh topik perjuangan kemerdekaan Palestina. Selain tindakan itu sama dengan bunuh diri dalam situasi yang tidak menguntungkan begini, pembicaraan terkait perang memang lebih efektif dilakukan di majelis rahasia (Hayya, 2019: 53).

Tak biasanya pak Wildan bicara pada mereka berdua dengan mimik serius saat itu. "Hayya hilang!" (Hayya, 2019: 110). 


\section{Bangga}

Bangga adalah perasaan puas terhadap apa yang dilihat, diraskan, terhadap sesuatu yang sesuai keinginannya. Bisa diartikan lain sebagai besar hati, merasa gagah karena memiliki keunggulan. Perasaaan bangga dalam novel di jelaskan melalui perkataan Abah kepada Rahmat. Hal tersebut di ucapkan secara terang-terangan oleh Abah pada Rahmat. Adapun hal tersebut dibuktikan melalui kutipan:

"Tidak ada yang serius, Rahmat. Abah hanya terharu karena begitu bahagia mendapati kamu sampai di titik ini." (Hayya, 2019: 67).

\section{Hening}

Hening adalah suasana yang menggambarkan diam, sunyi, sepi, dan lenggang. Bisa karena kondisi hari atau kondisi hati. Hening dalam novel diceritakan melalui pengarang yang ditujukan pada Rahmat. Berikut kutipan yang membuktikan suasana hening:

Lagi, hening. Kesabaran Rahmat sudah habis rupanya....(Hayya, 2019: 95).

\section{Kaget}

Kaget adalah kata sifat yang memiliki arti terperanjat atau terkejut karena heran atau terhadap sesuatu yang tiba-tiba. Adapun perasaan kaget dirasakan Adin ketika mendapati Hayya berada di rumah Rahmat. Hal tersebut dibuktikan melalui kutipan sebagai berikut:

Adin tak merespon. Mi di dalam mulutnya pun berhenti ia kunyah. Ia masih tak percaya kalau Hayya ada di depannya kini (Hayya, 2019: 121).

\section{Ceria}

Ceria adalah kata sifat yang memiliki arti berseri-seri, cerah, dan bahagia. Adapaun suasana ceria digambarkan melalui pengasuh Hayya yang bernama Ria. Ria yang digambarkan periang dan ceria itu bahkan tidak malu menyanyikan lagu kesukaan Hayya sepanjang perjalanan menuju Ciamis. Hal tersebut dibuktikan melalui kutipan sebagai berikut:

Ria tak henti menyenandungkan Dien Salam, lagu favoritnya. Suasana hatinya memang sedang gembira. Sepanjang perjalanan, gunung-gunung biru, perkebunan teh, ladang sayur-mayur, atau juga beberapa mall yang mentereng, benar-benar membuatnya tak sabar untuk tiba di lokasi piknik....(Hayya, 2019: 172).

\section{Meneganggakan}

Tegang adalah keadaan kaku, keras, dan kencang. Adapun menegangkan adalah kata turunan dari tegang. Suasana menegangkan terjadi ketika semua orang menyimpulkan bahwa Rahmat dan Ria memiliki hubungan, sebab Hayya memamnggil Rahmat sebagai Abi dan Ria dipanggil dengan sebutan Umi. Berikut suasana meneganggkan dibuktikan pada kutipan sebagai berikut:

Bi Nurul menggeleng-gelengkan kepala. "Bibi bener-bener tak menyangka kalau kamu akan berbuat setega ini pada kami semua, terutama pada Yasna keponakan Bibi." (Hayya, 2019: 181). 


\section{Haru}

Haru adalah keadaan hati yang perasa, peka, mudah iba, karena mendengar atau melihat sesuatu. Adapun didalam novel ini suasana haru terjadi ketika Hayya lari dan memeluk Rahmat, bahkan Hayya minta digendong. Hal tersebut dibuktikan melalui kutipan sebagai berikut:

Begitu pintu kamar dibuka, Rahmat langsung diserbu Hayya. Gadis kecil itu menangis. Ia segera minta digendong. Ketika menyaksikan Rahmat tadi dimarahi banyak orang...(Hayya, 2019: 188).

\section{Berhubungan dengan waktu}

Kejadian yang berkaitan dengan waktu pada novel Hayya terdapat beberapa, yang berkaitan dengan menit. Menit termasuk berhubungan dengan waktu. Adapaun di dalam novel ini dijelaskan beberapa melalui kutipan sebagai berikut:

Dua puluh menit lalu, Adin tahu kalau ada yang tak beres. Sebelum ketukan pintu yang terdengar agak serampangan itu singgah di gendang telinganya,....(Hayya, 2019: 12).

Kutipan lain yang sama-sama menunjukkan latar waktu berdasarkan menit, ditunjukkan oleh kutipan berikut:

Setelah lima belas menit berlari di dalam hutan, Adin merasa rombongan orang tak dikenal itu gagal mengendus jejaknya....(Hayya, 2019: 13).

Kutipan selanjutnya berdasarkan jam, berikut kutipan dari novel:

Pukul 4! Ya pukul 4! Dia tak ingin berangkat pukul 4.20 sebagaimana sebelum-sebelumnya. Kalau bisa sebelum pukul 4 pagi, batinnya lagi (Hayya, 2019: 60).

Kutipan selanjutnya menunjukkan latar waktu yang berkaitan dengan hari, ditunjukkan dengan kutipan:

Oh, besok ia akan pulang (Hayya, 2019: 72).

Kutipan berikutnya latar waktu yang berkaitan dengan tanggal dan bulan, berikut bukti kutipan:

Tiga belas Agustus 2019, kapal kemanusiaan Aman- Palestin merapat di Pelabuhan Tanjung Priok (Hayya, 2019: 74).

Sejak akhir tahun 2017, Adin bahkan lebih banyak tinggal di sana (Hayya, 2019: 79).

Kutipan berikutnya menunjukkan latar waktu yang berkaitan dengan waktu salat, ditunjukkan melalui kutipan berikut:

Kumandang azan subuh dari masjid kompleks hampir selesai (Hayya, 2019: 97).

Menjelang Zuhur mereka tiba di lokasi tujuan. Sebuah rumah dengan pekarangan yang luas dan asri...(Hayya, 2019: 173).

Malam itu, kediaman Kiai Zainal mulai ramai (Hayya, 2019: 189).

"Sore itu, sebelum magrib, Abrar membaca running-text di program berita di GNN....(Hayya, 2019: 206).

\section{Alur}

Alur yang digunakan dalam novel ini adalah alur campuran. Namun dari keseluruhan alur dalam novel, lebih banyak menggunakan alur maju. Novel ini menggunakan alur mundur di awal pada sub bab "Awas Anjing Galak!". Pada paragraf pertama pengarang memaparkan penyebab Adin di kejar Anjing pada saat acara sakral Rahmat. Kemuadian alur maju mulai digunakan ketika masuk sub bab baru “ Di Ramallah”, 
yang menceritakan keadaan Rahmat selama menjadi Relawan kemanusiaan berlanjut hingga bertemu Hayya, menikah dengan Yasna, dan berpisah dengan Hayya.

\section{Kutipan yang menunjukkan alur mundur dalam novel}

"Adin tidak pernah mengira kalau pagi yang sakral bagi Rahmat Assyraf Pranaja justru menyeretnya pada kekacauan seperti ini. Kekacauan yang mau tidak mau harus ia hadapi sebab keadaan sudah mengisapnya hingga ke dasar pusaran. Ia tidak mungkin mundur; apalagi untuk sekedar memberikan klarifikasi; bahwa ia bukanlah aktor semua ini, bahwa ia hanyalah cameo sebuah film yang tak sempat ia baca utuh skenario sebelum menandatangani kontrak; bahwa ia hanya apes ketiban getah ketika Rahmat sedang makan nangka. Namun siapa mau percaya? (Hayya, 2019: 11).

Dua puluh menit lalu, Adin tahu kalau ada yang tak beres. Sebelum ketukan pintu yang terdengar agak serampangan itu singgah di gendang telinganya, derap langkah orang-orang di kejauhan yang makin lama makin dekat, membuatnya bergegas mengambil kain gendongan dan menaruh Hayya di dalamnya. Gadis lima tahun itu, seperti selalu percaya dengan apa yang Adin lakukan. Menurut saja (Hayya, 2019: 12).

"oh Ukhti Afifah di Palestina!" pekik Rahmat tertahan. "Saya ingat sekarang. Apa hubungannya dengan semua ini?"

"Berita hilangnya Hayya sampai ke Ramallah. Afifah sudah menyampaikan kesaksiannya kepada AmanPalestin lewat sambungan telepon perihal Hayya yang sengaja masuk koper. Kala itu Afifah tidak menganggapnya sebagai hal yang serius sebab koper itu katanya sudah kamu hibahkan ke Ramallah untuk mengangkut logistik kalau kamp pengungsian harus berpindah. Afifah tak pernah menyangka kalau Hayya melakukan itu semua untuk menyusulmu. Afifah tak menyangka kalau Hayya akan tiba di Indonesia. Barusan, Dubes Palestina meminta urusan ini tidak sampai ke kepolisisan dan meminta kalian dibebaskan dari tuduhan. Tapi wartawan kadung tahu. Mungkin satu dua jam lagi. Konferensi pers akan digelar. Saran ana, silahkan ganti pakaian dulu. relawan telah menyiapkannya. Tenang, semua sudah terkendali. Jangan canggung, kita paham keadaannya." Jelas Pak Yusuf panjang lebar (Hayya, 2019: 254-255).

Pada kutipan pertama merupakan alur mundur yang dijelaskan oleh penjelasan tokoh Adin. Kutipan kedua dijelaskan oleh pengarang dan kutipan ketiga dijelaskan oleh tohoh Rahmat.

\section{Kutipan yang menunjukkan alur maju dalam novel}

“......wajahnya kusut, daging keningnya berlipat tiga, matanya yang menyipit menengadah ke arah matahari, tetap tak mampu menyamarkan kegelisahan yang menindih di kepalanya, paling tidak di hadapan Adin Abdul Hakim, sahabat yang sudah nyaris sepuluh tahun menjadi satu-satunya orang yang memahaminya sekaligus paling betah dan bebal dengan semua watak keras kepalanya (Hayya, 2019: 19).

Rahmat menggantung handuk yang baru digunakan di balik pintu, lalu meraih mushaf dari kantong luar ranselnya. Lima menit kemudian ia sudah mengaji dengan air mata yang tak kuasa ia kendalikan.

Palestina.

Abah.

Palestina.

Yasna.

Palestina.

Hayya.

Rahat memandangi Adin yang sudah terlelap dengan kaki mengepit bantal. Tiga puluh menit kemudian, tepat pukul setengah dua belas malam. Ia mencium mushaf lama. Lama sekali (Hayya, 2019: 62).

Tiga belas Agustus 2019, kapal kemanusian Aman-Palestin merapat ke Pelabuhan Tanjung Priok. Seperti mengolok-olok perasaannya yang sendu dan kusut, langit Jakarta malam itu lebih gelap dari biasanya. Lebih murung dari biasa. Lebih lengang dari biasa. Sedari dermaga hingga mobil boks- yang membawa barang- 
barang relawan- yang ditumpanginya masuk ke jalan raya, Rahmat tak mengeluarkan sepatah kata pun (Hayya, 2019: 74).

Kutipan-kutipan tersebut menunjukkan alur maju. Karena menggambarkan kondisi atau perjalanan hidup tokoh Rahmat dari Palestina hingga kembali Indonesia.

\section{Sudut pandang}

Sudut pandang adalah sebutan untuk mengganti nama tokoh dalam cerita, dan keberadaan narator dalam cerita. Dalam novel Hayya Karya Helvy Tiana Rosa dan Benny Arnas, pengarang bercerita dengan memosisikan dirinya sebagai orang ketiga. Sebagai orang ketiga, pengarang adalah seorang yang berada di luar cerita, yang menampilkan tokoh-tokoh cerita dengan menyebutkan nama, atau kata ganti ia, dia, mereka. Nama-nama tokoh, khususnya yang utama, kerap atau terus menerus disebut, dan sebagai variasi dipergunakan kata ganti. Hal tersebut dapat dilihat dari kutipan berikut:

Walaupun Adin dan Rahmat sudah tahu kalau wilayah Masjidil Aqsa berjarak tak sampai 80 kilometer dari Jalur Gaza yang menjadi pusat konflik tiada henti, namun mereka selalu mengharap berita baik dari anggota rombongan lain kalau-kalau ada kemungkinan mereka bisa menjangkau daerah itu (Hayya, 2019: 29).

Masjidil Aqsa memang tidak terbuka setiap saat sejak dikuasai Israel. Mereka hanya membukanya 16 jam setiap hari. Dibuka pukul 4 subuh dan tutup pukul 8 malam alias hanya memberikan waktu 30 menit untuk menunaikan ibadah sunnah menjelang subuh dan bakda isya. Maka ketika Rahmat dan Adin bisa salat sunnah di Aqsa hingga pukul 8 lewat malam ini, wajar kalau Pak Haidar memohon agar mereka menyudahinya segera. Tentu saja itu bukan tentang keselamatannya sebagai muslim yang menjaga Aqsa. Lebih dari itu, itu adalah tentang keselamatan dua saudaranya yang berasal dari Indonesia (Hayya, 2019: 60).

Dari kedua kutipan di atas, dapat diketahui bahwa pengarang memosisikan dirinya sebagai orang ketiga serba tahu. Pengarang mengetahui segala hal tentang tokoh, peristiwa dan tindakan, motivasi yang melatarbelakangi tokoh dalam mengambil suatu tindakan. Selain itu, pengarang juga mengetahui tentang pikiran, perasaan dan pandangantokoh cerita. Namun sebagai orang ketiga pengarang tidak terlibat dalam alur cerita karena hanya sebagai pengamat atau dalang yang serba tahu.

\section{NILAI-NILAI PENDIDIKAN}

Seperti pendapat Octaviana bahwa beberapa nilai positif yang hadir dalam karya sastra seperti novel merupakan nilai pendidikan yang didalamnya mencakup nilai budaya, nilai moral, nilai agama dan nilai sosial (2018: 183). Hakikat pendidikan sendiri adalah memperlakukan manusia seperti layaknya seorang manusia. Humanisasi atau memperlakukan manusia atau melihat manusia sebagai suatu keseluruhan didalam keberadaannya. Eksistensi tersebut adalah memberikan tempat manusia nilai-nilai yang tinggi demi menjunjung martabatnya (Tilaar, 2012: 424).

Adler (dalam Arifin, 2012: 13) juga berpendapat bahwa pendidikan merupakan salah satu proses dari seluruh kemampuan manusia yang dipengaruhi oleh kebiasaan baik untuk membantu dirinya sendiri dan orang lain dalam mencapai suatu kebiasaan yang baik. Sementara Hasbullah (2013: 1) menyatakan adapun pendidikan ialah sebuah usaha dari manusia untuk membangun kepribadiannya berdasarkan nilai-nilai dalam kebudayaan dan masyarakat.

Dalam kaitannya terhadap sastra, ia juga merupakan alat untuk mendidik. Bahkan hampir semua, karya sastra tergolong sarana-sarana beretika. Jadi sastra dan pendidikan merupakan dua hal yang saling berkaitan. Berdasarkan berbagai pendapat diatas dapat ditarik kesimpulan terkait nilai pendidikan adalah segala sesuatu yang baik atau buruk, berguna bagi manusia dan bisa didapatkan dalam pembelajaran. Berkaitan dengan eksistensi manusia, nilai-nilai pendidikan berupa:

\section{Nilai Pendidikan Religius}


Religius berbaitan dengan masalah ketuhanan. Rosyadi (1995: 90) menyatakan bahwa religi bukan hanya menyinggung dari segi kehidupan lahiriah termasuk keseluruhan diri manusia secara total dalam hubungannya terhadap keesaan Tuhan yang Maha Esa. Religius merupakan sebuah nilai hidup manusia yang dapat dimaknai sebagai rasa kebersamaan yang menyatu pada sesuatu yang tidak dapat terlihat hanya dengan seseorang seperti agama, tetapi religius itu merupakan kegiatan yang dilakukan seseorang secara konsisten dalam kehidupannya (Awalia, Rasyid dan Zuriyati, 2019: 87).

Nilai -nilai religius bertujuan untuk mendidik manusia agar hidup sesuai dengan ajaran agama dan senantiasa ingat kepada Tuhan. Sedangkan nilai religius dalam karya sastra bertujuan untuk pembaca melakukan kontemplasi terhadap isi dalam karya sastra sehingga bisa diimplementasikan dalam kehidupan sehari-hari.

Adanya unsur religius di dalam sastra adalah seusia dengan awal kemunculan sastra. Bahkan, sastra tumbuh dan berkembang dari sesuatu yang religius. Istilah religius ini membawa konotasi pada sebuah makna agama (Nurgiyantoro, 2012: 326-327).

Nilai religius berkaitan dengan ketuhanan dan agama yang memiliki tujuan mendidik manusia agar hidup sesuai dengan ajaran dan ingat terhadap Tuhan. Nilai pendidikan religius dalam novel Hayya karya Helvy Tiana Rosa dan Benny Arnas berkaitan dengan hati nurani atau kerohanian pribadi tokoh yang bersumber dari kepercayaan atau keyakinan manusia. Hal tersebut tergambar dalam novel Hayya karya Helvy Tiana Rosa dan Benny Arnas sebagai berikut:

Tiga puluh menit kemudian, tepat pukul setengah dua belas malam ia mencium mushaf lama. Lama sekali (Hayya, 2019: 62).

Kutipan tersebut menunjukkan bagaimana Rahmat sangat mencintai quran, sebagai seorang muslim yang taat pada agama, ia senantiasa menjalankan perintah dan kewajibannya. Termasuk membaca quran adalah salah satu cara mendekatakan diri dengan Allah.

“Sekarang sehat alhamdulillah.” Akhirnya abahnya menjawab juga......(Hayya, 2019: 66).

Kutipan tersebutmerupakan salah satu kalimat zikir untuk menunjukkan rasa syukur atas nikmat yang diberikan oleh Allah SWT. Kalimat itu diucapkan abah ketika ditanya tentang kabar oleh Rahmat, putranya.

"sampai akhirnya kamu pun melonjak kegirangan ketika tahun lalu kamu ditugaskan ke Palestina tigaempat bulan. Abah tahu, kegembiraannmu bukan karena kamu dapat plesiran gratis, melainkan wujud syukurmu bisa menginjakkan kaki di Tanah Anbiya untuk merasakan gejolak di Gaza dan daerah konflik lainnya di sana. 'Aku siap turun langsung di medan perang, mengumpulkan kerikil dan batu-batu lalu melemparnya ke pasukan Zionis laknatullah!' serumu penuhkegeraman waktu itu.....(Hayya, 2019: 68).

Kutipan tersebut menggambarkan perjuangan Rahmat di jalan Allah (jihad di medan).

"Jaga dirilah baik-baik di sana, nak." "Insyaallah, bah.” (Hayya, 2019: 69).

Kutipan tersebut merupakan perkataan yang mengandung arti semoga Allah mengizinkan, apapun yang terjadi semua tidak terlepas dari campur tangan Allah termasuk kesehatan. Hal tersebut diucapkan Rahmat untuk menjawab pesan Abah.

Seorang perempuan berwajah ayu, tanpa riasan wajah, berjilbab krem tua, dengan mata yang kuasa menembus dan meneroka lekuk terdalam hatinyayang sepi. Yasna, batinnya. Setelah mengelus-elus permukaan foto, hampir saja kertas mengilap itu ia arahkan ke wajahnya ketika istighfar serta merta keluar dari bibirnya. Ya Allah maafkan kehilafan hamba, batinnya lagi seraya meletakkan foto berukuran $2 \mathrm{R}$ itu diatas meja kecil di samping dipan...(Hayya, 2019: 79). 
Kutipan tersebut menunjukkan bahwa Rahmat sadar, Yasna belumlah halal baginya, mereka belum menikah. Jadi mencium fotonya saja tidak diperbolehkan.

Jadi, nilai religius berkaitan dengan ketuhanan dan agama yang memiliki tujuan mendidik manusia agar hidup sesuai dengan ajaran dan ingat terhadap Tuhan.

\section{Nilai Pendidikan Sosial}

Manusia adalah makhluk sosial yang pastinya memiliki hubungan dengan manusia lain untuk memenuhi kebutuhannya. Dalam berhubungan dengan orang lain, manusia perlu menerapkan berbagai nilai sosial yang berlaku dalam lingkungan masyarakat agar tidak terjadi konflik sosial.

Nilai sosial mengarah pada pertimbangan terhadap cara untuk memutuskan apakah sesuatu yang bernilai itu bernilai kebenaran, tindakan benda, keindahan, dan nilai ketuhanan. Sementara itu, Rosyadi (1995: 80) menyatakan bahwa kesadaran manusia terhadap pentingnya kehidupan dalam ikatan keluarga dan kelompok anatara satu dengan yang lain melalui nilai pendidikan sosial.

Adapun nilai sosial dalam novel Hayya karya Helvy Tiana Rosa dan Benny Arnas sebagai berikut:

“.....tapi saya juga jarang ke sini. Malam ini, kebetulan jalan sama teman-teman, saya ingin jadi tuan rumah yang baik," katanya kemudian. Lalu ia menyilahkan kami minum sahlab di atas meja. Tak lama kemudian salah seorang rekannya masuk ke rumah. "Dia sedang membuat sahlab lagi. Jangan khawatir, ayo cicipilah. Anggap saja ini minuman perkenalan untuk saudara-saudara kami dari Indonesia!” (Hayya, 2019: 49).

Kutipan di atas menggambarkan nilai sosial orang Palestina terhadap tamu. Mereka ingin memuliakan tamu, dengan memberikan hidangan terbaik.

Jadi, nilai sosial mengarah pada hubungan antarindividu dalam suatu kelompok masyarakat. Oleh sebab itu, nilai-nilai pendidikan sosial dapat dirumuskan sebagai kumpulan berbagai perasaan dan sikap seseorang yang diimplementasikan lewat sikap dan tindakan sehari-hari yang mempengaruhi seseorang dalam berhubungan dengan individu yang lain. Nilai pendidikan sosial berisi kumpulan perasaan dan sikap yang diterima secara luas dan menyeluruh oleh masyarakat untuk membuat sebuah keputusan terhadap sesuatu yang penting dan benar.

\section{Nilai Pendidikan Budaya}

Nilai budaya suatu masyarakat belum tentu sama dengan nilai budaya masyarakat lain karena ditentukan oleh kondisi kultural dan konstruk pemahaman suatu masyarakat tertentu. Oleh karena itu nilai budaya merupakan tingkat yang paling abstrak dari hidup, adat, dan mendarah daging dalam pemikiran masyarakat sehingga tidak mudah diubah atau dihilangkan dengan nilai budaya yang lain apalagi dalam kurun waktu yang sebentar.

Pemahaman nilai budaya dalam kehidupan manusia didapatkan karena manusia memaknai waktu dan ruang. Makna itu akan berupa intersubjektif karena ditumbuhkembangkan secara individual, tetapi dihayati secara bersamaan, disetujui, diterima oleh masyarakat sehingga menjadikan latar budaya yang terpadu bagi peristiwa yang digambarkan. Sistem dari nilai budaya terdiri dari beberapa konsep yang hidup pada logika dan pikiran sebagai masyarakat terhadap hal-hal yang harus dianggap memiliki nilai dalam hidup karena sistem nilai budaya biasanya memiliki fungsi sebagai pedoman tertinggi bagi tindakan dan sikap manusia. Adapun nilai-nilai budaya dalam sebuah karya sastra (novel) dapat diketahui melalui perilaku dan karakteristik antartokoh yang baik atau buruk (Isnaniah, 2014: 94).

Berdasarkan berbagai penjelasan diatas dapat ditarik kesimpulan bahwa sistem nilai budaya adalah kerangka yang penting dalam suatu kebudayaan artinya ia bersifat samar, abstrak dan hanya dapat didapatkan melalui pengamatan pada suatu gejala nyata seperti beebagai benda material sebagai hasil 
perenungan konsep dari suatu nilai tindakan yang terkonsep dan perilaku manusia. Adapun pendidikan budaya dalam novel Hayya karya Helvy Tiana Rosa dan Benny Arnas sebagai berikut:

Rahmat sebenarnya tidak terlalu menyukai keramaian seperti malam itu, tapi ia tak bisa menghindar. Sepanjang acara, Adin tak henti memberikan kode agar Rahmat tidak memasang wajah bete. Sebelumnya, Adin memang sudah wanti-wanti agar Rahmat mengikuti saja kebiasaan masyarakat Ciamis. Adat di daerah tentu berbeda di Jakarta menyerahkan segala urusan kepada wedding organizer (Hayya, 2019: 189).

Setiap daerah akan memiliki budaya yang berbeda apalagi urusan pernikahan, kutipan diatas menunjukkan sikap Rahmat yang kurang senang dengan adat kebiasaan pernikahan di Ciamis.

\section{Pendidikan Karakter}

Pendidikan karakter merupakan hal terpenting sebab kaitannya tidak hanya tentang seseorang dengan pendidikan tetapi berefek pada kehidupan. Ketika seseorang menempuh jalan pendidikan pembelajaran nilai karakterpun akan ikut terbentuk. Bukan hal yang mudah namun juga tidaklah sulit, tetapi memang pembiasaan untuk mengerjakan hal-hal yang baik dan juga bernilai positif.

Rasa tanggung jawab, rasa hormat dan seluruh nilai yang lain berasal dari kedua nilai ini dapat memberikan pelajaran moral yang seharusnya diajarkan oleh pihak sekolah pada sebuah demokrasi. Tetapi, sekolah tidak hanya membutuhkan dalam bentuk nilai atau angka. Padahal esensi dari karakter ini adalah moral yang baik, dan itu tidak mungkin didapat dalam waktu singkat. Maka pentingnya sekolah memiliki konsep karakter dan komitmen untuk mengembangkan konsep yang telah dirancangnya bersama peserta didik.

Tutu mengatakan agar dapat memahami karakteristik atau penokohan dalam suatu karya sastra melalui membaca dan mengikuti cerita hingga ending/ akhir secara runtut. Sebab karakter bisa disebut dengan tabiat, watak, sifat, dan corak pribadi. Secara singkat diartikan sebagai kondisi jiwa manusia yang diakibatkan oleh faktor dari luar maupun dari dalam yang membedakan dengan orang lain (2019: 20-22).

Lickona (2012: 80-81) menjelaskan perkembangan etika yang paling signifikan selama dua dekade terdahulu ialah pendalaman karakter dan perhatian. Hubungan sebuah karakter privat dan kehidupan publik, diskusi ilmiah, permasalahan moral masyarakat menunjukan sebagian besar pribadi tiap individu, analisis media dan pembicaraan sehari-hari kesemuanya fokus pada karakter para generasi muda, pemimpin terpilih, dan warga negara.

Adapun menurut Ki Hajar (dalam Muthoifin dan Jinan, 2015, 172) menyimpulkan bahwa pendidikan sikap berupa budi pekerti tidaklah mengajarkan teori tentang baik buruknya melalui dalil-dalil yang rumit tetapi pendidikan budi pekerti ialah pembiasaan berbuat baik pada anak pada kehidupan sehari-hari. Ki Hajar menginginkan dalam pengajaran di bidang studi apapun haruslah mengintegrasikannya dengan pendidikan budi pekerti.

Sedangkan menurut Musfiroh (2008: 27)Karakter mengarah pada serangkaian motivasi, perilaku, sikap, dan keterampilan. Sebagai penggambaran perbuatan yang mencerminkan nilai salah-benar, baik secara implisit ataupun eksplisit. Karakter berwujud tingkah laku yang ditunjukan untuk lingkungan sosial sehingga jika terdapat orang yang suka menolong, empati terhadap orang lain, bersedah merupakan orang yang berkarakter karena perilakunya sesuai dengan moral.

Melalui tema dapat dilihat bentuk sederhana dalam pemerolehan moral, akan tetapi tidak semua tema pasti moral (Kenny dalam Nurgiyantoro, 2012: 320). Moral adalah pandangan dari penulis terhadap nilai-nilai kebenaran yang ditujukan kepada pembaca. Jadi, moral berisi makna yang termasuk dalam karya sastra baik tersirat maupun tersurat yang disampaikan lewat cerita agar dibaca, dipahami, dan diamalkan oleh pembaca. Moral juga dapat diartikan dengan kemampuan seseorang dalam membedakan antara hal yang buruk dan baik, merupakan pendapat Hasbullah (dalam Isnaniah, 2014: 95-96). 
Pentingnya pengetahuan etika dari keluarga dan lingkungan yang baik sangat membantu anak dalam membentuk karakter. Sebelum mereka memasuki bangku sekolah akan lebih baik jika sudah memiliki bekal yang baik. Aristoteles merupakan seorang filsuf yang berasal dari Yunani mendefinisikan tentang karakter yang baik dalam kehidupan yaitu dengan mengerjakan hal-hal yang benar, berkaitan dengan orang lain dan diri seseorang. Termasuk berbudi luhur, ia jelaskan karena termasuk kebaikan yang berorientasi pada diri sendiri. Maka manusia perlu mengendalikan hasrat, dirinya sendiri, keinginan, untuk melakukan tindakan baik pada orang lain (Lickona, 2012:81).

Berdasarkan berbagai penjelasan sebelumnya dapat diambil kesimpulan bahwa nilai pendidikan moral berkaitan dengan norma dan aturan tingkah laku dalam suatu masyarakat yang wajib dipatuhi oleh semua elemen masyarakat. Pendidikan karakter adalah pendididkan budi pekerti lebih, yaitu yang mengikutsertakan aspek tindakan, perasaan, dan pengetahuan (Licona, 2012: 84).

Adapun nilai moral dalam novel Hayya karya Helvy Tiana Rosa dan Benny Arnas yaitu sebagai berikut:

“Kamu kenapa sih, Brar?” Yasna gusar. "Suka sekali merusak suasana.” Ia benar-benar heran dengan Abrar yang menurutnya tak bisa bersikap lemah lembut dengan calon kakak iparnya.

"Bukan begitu, Teh."

"Bukan apanya? Kamu teh nggak suka kalau kakak nikah? Nggak senang kalau Rahmat jadi kakak iparmu? Kan kamu lihat sendiri kalau dia sudah hijrah? Kita juga jadi saksi bersama bagaimana Kang Rahmat menulis tentang aksi 212 dengan begitu menggugah. Kita tidak tahu bagaimana Allah menyiapkan segalanya." Mata Yasna berkaca-kaca (Hayya, 2019: 179).

Kutipan tersebut merupakan sikap kurang baik Abrar terhadap orang yang lebih tua darinya, meskipun ia peka terhadap keganjalan yang dirasakan Rahmat. Bukan berarti ia mencerca Rahmat dan sebagai kakak Yasna menegur Abrar.

\section{SIMPULAN DAN SARAN}

\section{Simpulan}

Berdasarkan deskripsi pada hasil penelitian diatas, maka dapat disimpulkan bahwa:

1. Keterikatan unsur-unsur yang membentuk struktural novel Hayya yang meliputi: Tema, tokoh dan penokohan, latar, alur, dan sudut pandang. Tema dalam novel Hayya adalah perjuangan Rahmat untuk menjaga Hayya dengan menghadapi rintangan baik dari luar maupun dalam. Tema tersebut di wujudkan dalam konflik tokoh-tokoh terhadap nilai-nilai yang telah diakui oleh masyarakatnya. Serta perjalanan cinta Rahmat untuk menghalalkan Yasna. Tokoh Hayya merupakan tokoh utama cerita, sedangkan tokoh utama bawahan adalah tokoh Rahmat. Adapun tokoh-tokoh lain dalam novel ini adalah tokoh Adin, Ria, Yasna, Abah, Bi Nurul, Abrar, Pak Wildan, dan Ustadzah Khalida. Latar dalam novel ini secara garis besar meliputi dua tempat yaitu Palestina dan Indonesia. Alur novel Hayya ini terbagi menjadi alur utama (alur mayor) dan alur bawahan (alur minor). Alur mayor jalinan peristiwa tentang perjalanan tokoh Rahmat dari menjadi Relawan kemanusiaan di Palestina hingga kembali ke Indonesia dan menikah. Alur ini memiliki kecenderungan maju (progesif). Adapun alur minor merupakan jalinan peristiwa tokoh Adin di Ciamis menggendong Hayya. Alur minor dalam novel ini memiliki urutan kisah yang bersifat (regresif). Mudahnya kita sebut novel ini menggunakan alur campuran. Sudut pandang dalam novel ini pengarang sebagai orang ketiga yang serba tahu.

2. Keterikatan novel Hayya karya Helvy Tiana Rosa dan Benny Arnas meliputi: nilai pendidikan religius, nilai pendidikan sosial, nilai pendidikan budaya, dan nilai pendidikan karakter. Nilai pendidikan religius dalam novel ini membaca quran, mengucapkan kalimat toyyibah (kalimat yang baik), dzikir, berjuang di jalan Allah (jihad), dan zina perasaan. Nilai pendidikan sosial 
dalam novel ini adalah memuliakan tamu serta adab bertamu. Nilai pendidikan budaya dalam novel ini adalah adat pernikahan daerah Ciamis tentu berbeda dengan di Jakarta yang cenderung menggunakan Wedding Organizer. Nilai pendidikan karakter dalam novel ini adalah menghormati orang yang lebih tua.

\section{Saran} berikut.

Berkaitan dengan hasil yang dicapai penelitian di atas, peneliti mengajukan saran-saran sebagai

1. Bagi siswa

Bagi siswa, hendakknya dapat membaca novel dan mengambil nilai-nilai positif melalui nilai-nilai pendidikan dalam novel sehingga dapat diaplikasikan dalam kehidupan sehari-hari, sehingga ada keseimbangan antara yang dipelajari dengan aplikasi. Kemudian untuk nilai-nilai negatif/ buruk dalam novel menjadi pembelajaran untuk tidak ditiru.

2. Bagi guru

Bagi guru bahasa dan sastra Indonesia, agar hasil penelitian ini dapat dipergunakan sebagai bahan masukan atau pertimbangan serta bahan ajar dalam pembelajaran bahasa dan satra Indonesia yang dapat membantu siswa menerima dan memahami materi sastra.

3. Bagi pembaca

Bagi para pembaca karya sastra, hendaknya mengambil nilai-nilai positif yang ditampilkan pada novel. Novel Hayya karya Helvy Tiana Rosa dan Benny Arnas merupakan novel terbitan Aman-Palestin yang menarik untuk dibaca, sehingga menambah wawasan baru bagi pembaca khusunya perjuangan seseorang yang berada di Palestina.

4. Bagi peneliti lain

Bagi peneliti lain, sebaiknya terus meningkatkan penelitian di bidang sastra khususnya novel Hayya karya Helvy Tiana Rosa dan Benny Arnas. Supaya dapat menambah literasi terutama dalam sebuah penelitian berkaitan dengan kesusasasteraan.

\section{DAFTAR PUSTAKA}

Akbar, Winarni dan Andayani. 2013. "Kajian Sosiologi Sastra dan Nilai Pendidikan Dalam Novel "Tuan Guru” Karya Salman Faris". Magister Pendidikan Bahasa dan Sastra Universitas Sebelas Maret. Jurnal Pendidikan Bahasa dan Sastra Vol 1 (1). p.54-68

Arifin, Muzayyin. 2012. Filsafat Pendidikan Islam. Jakarta: Bumi Aksara.

Awalia, Rasyid dan Zuriyati. 2019. "Nilai-Nilai Religius Dalam Kumpulan Puisi Tadarus Karya KH. Ahmad Mustofa Bisri”. Universitas Negeri Jakarta. Jurnal ILE\&L. Vol. 5 (1).p.87

Endraswara, Suwardi. 2013. Metodologi Penelitian Sastra. Jakarta: CAPS (Center fir Academic Publishing Service).

Esten, Mursal. 2013. Kesusasteraan Pengantar Teori dan Sejarah. Bandung: Penerbit Angkasa.

Hasbullah. 2013. Dasar-dasar Ilmu Pendidikan. Jakarta: Raja Grafindo Persada.

Hikmasari, Miftahurohmah dan Sahayu Wening. 2019. "Unsur Budaya Material Dalam Novel Entrok Karya Okky Madasari”. Jurnal Atavisme . Vol. 22 (2).p.204

Istiqomah, Fathia. 2014. "Nilai-Nilai Pendidikan Karakter Dalam Novel 9 Matahari Karya Adenita". Jurnal Raushan Fikr STAIN Purwokerto. Vol.4 (2). p.99 
Isnaniah, Siti. 2014. Representasi Ajaran Islam Dalam Novel-Novel Karya Habiburrahman El-Shirazy. Surakarta: Program Pascasarjana UNS Surakarta.

Junaini, Agustina dan Canrhas. 2017. “Analilis Nilai Pendidikan Karakter Dalam Cerita Rakyat Seluma”. Jurnal Korpus. Vol. 1 (1).p.39

Kurniawan. 2001. Semilogi Roland Barthes. Magelang: Penerbit Yayasan Indonesiatera

Lickona, Thomas. 2012. Educating For Character Mendidik Untuk Membentuk Karakter. Jakarta: Bumi Aksara.

Luxembung, Bal, dan Weststteijn. 1986. Pengantar Ilmu Sastra. Jakarta: PT Gramedia.

Maxwell, Joseph A. 1996. Qualitative Reserch Design An Interactive Apporch. California, London, New Delhi: Sage Publication.

Miles, Mattew B dan A. Michael Huberman. 1992. Analilis Data Kualitatif. Jakarta: UI Press.

Musfiroh, Tadzkirotun. 2008. Character Building Bagaimana Mendidik Anak Berkarter? Penyunting Arismantoro. Yogyakarta: lembaga Penelitian UNY dan Tiara Wacana.

Muthoifin dan Jinan. 2015. "Pendidikan Karakter Ki Hadjar Dewantara: Studi Kritis Pemikiran Karakter Dan Budi Pekerti Dalam Tinjauan Islam”. Jurnal Profetika. Vol.16 (2).p.172

Octaviana, Dwi Warry. 2018. "Analisis Nilai-Nilai Pendidikan dalam Novel Uhibbuka Fillah (Aku Mencintaimu Karena Allah) Karya Ririn Rahayu Astuti Ningrum: Kajian Sosiologi Sastra”. Jurnal KATA. Vol. 2 (2).p. 183

Nurgiyantoro, Burhan. 2012. Teori Pengkajian Fiksi. Yogyakarta: Gajah Mada University Press.

Rosa, Helvy Tiana dan Arnas, Benny. 2019. Hayya. Bandung: AmanPalestin

Rosyadi. 1995. Nilai-nilai Budaya dalam Naskah Kaba. Jakarta: CV Dewi Sri.

Sujarwanto, Al-Ma'ruf, dan Sunanda. 2018. Nilai Budaya Pada Novel Anak Rantau Karya Ahmad Fuadi: Kajian Antropologi Sastra dan Implementasinya Dalam Pembelajaran Sastra di SMA. Universitas Muhammadiyah Surakarta.

Suwarno, Asri Kartika Dewi. 2012. Analisis Struktural Pada Novel Sirah! Karya A.Y. Suharyono Dan Pembelajarannya DI SMA. Universitas Muhamadiyah Purworejo.

Syarifuddin. 2018. “Kajian Struktural Dan Sosiologi Sastra Dalam Novel Seputih Hati yang Tercabik”. Jurnal KATA. Vol. 2 (2). p. 205

Tilaar, H. A. 2012. Perubahan Sosial dan Pendidikan: Pengantar Pedagogik Transformatif untuk Indonesia. Jakarta: Rienaka Cipta

Waluyo, Herman J. 1994. Pengkajian Cerita Fiksi. Surakarta: Sebelas Maret University Press. 